\title{
Regulation of TRH neurons and energy homeostasis-related signals under stress
}

\author{
Patricia Joseph-Bravo, Lorraine Jaimes-Hoy and Jean-Louis Charli \\ Departamento de Genética del Desarrollo y Fisiología Molecular, Instituto de Biotecnología, Universidad Nacional \\ Autónoma de México (UNAM), A.P. 510-3, Cuernavaca, Morelos 62250, Mexico
}

Correspondence should be addressed to $\mathrm{P}$ Joseph-Bravo Email joseph@ibt.unam.mx

\begin{abstract}
Energy homeostasis relies on a concerted response of the nervous and endocrine systems to signals evoked by intake, storage, and expenditure of fuels. Glucocorticoids (GCs) and thyroid hormones are involved in meeting immediate energy demands, thus placing the hypothalamo-pituitary-thyroid (HPT) and hypothalamo-pituitary-adrenal axes at a central interface. This review describes the mode of regulation of hypophysiotropic TRHergic neurons and the evidence supporting the concept that they act as metabolic integrators. Emphasis has been be placed on i) the effects of GCs on the modulation of transcription of Trh in vivo and in vitro, ii) the physiological and molecular mechanisms by which acute or chronic situations of stress and energy demands affect the activity of TRHergic neurons and the HPT axis, and iii) the less explored role of non-hypophysiotropic hypothalamic TRH neurons. The partial evidence gathered so far is indicative of a contrasting involvement of distinct TRH cell types, manifested through variability in cellular phenotype and physiology, including rapid responses to energy demands for thermogenesis or physical activity and nutritional status that may be modified according to stress history.
\end{abstract}
Key Words
- HPA
HPT
- stress
metabolism

\section{Introduction}

The tripeptide pglu-his-proNH2 was isolated from hypothalami and named according to its endocrine function: 'thyrotrophin-releasing hormone' (TRH; Boler et al. 1969, Burgus et al. 1969). TRH is synthesized in the neuronal cell bodies of many brain regions from a precursor protein, prepro-TRH (ppTRH), and processed to yield the biological active peptide (Lechan et al. 1986, Lechan \& Segerson 1989, Nillni 2010). Several hypothalamic nuclei synthesize TRH (Fig. 1), but the TRH neurons that control thyrotrophin (TSH) release are the hypophysiotropic neurons present in the mid-caudal paraventricular nucleus (PVN) (anterior-medial PVN in mouse), whose axons project to the median eminence from where TRH is released into the portal vessels of the hypothalamo-pituitary system (Fekete \& Lechan 2014; Fig. 1). In humans, hypophysiotropic TRH neurons are present in the medial region of the dorsocaudal portion of the PVN (Fliers et al. 2014).

The amount of released TRH that reaches the pituitary is modulated in the median-eminence extracellular space by the activity of the TRH-degrading ectoenzyme (pyroglutamyl peptidase II (PPII)) present on tanycytes, a group of ependymal cells lining the third ventricle whose end-feet are in proximity with TRH terminals and portal vessels (Sánchez et al. 2009). In the pituitary and upon binding to its receptor (TRH-R1), TRH controls the release

Published by Bioscientifica Ltd. 


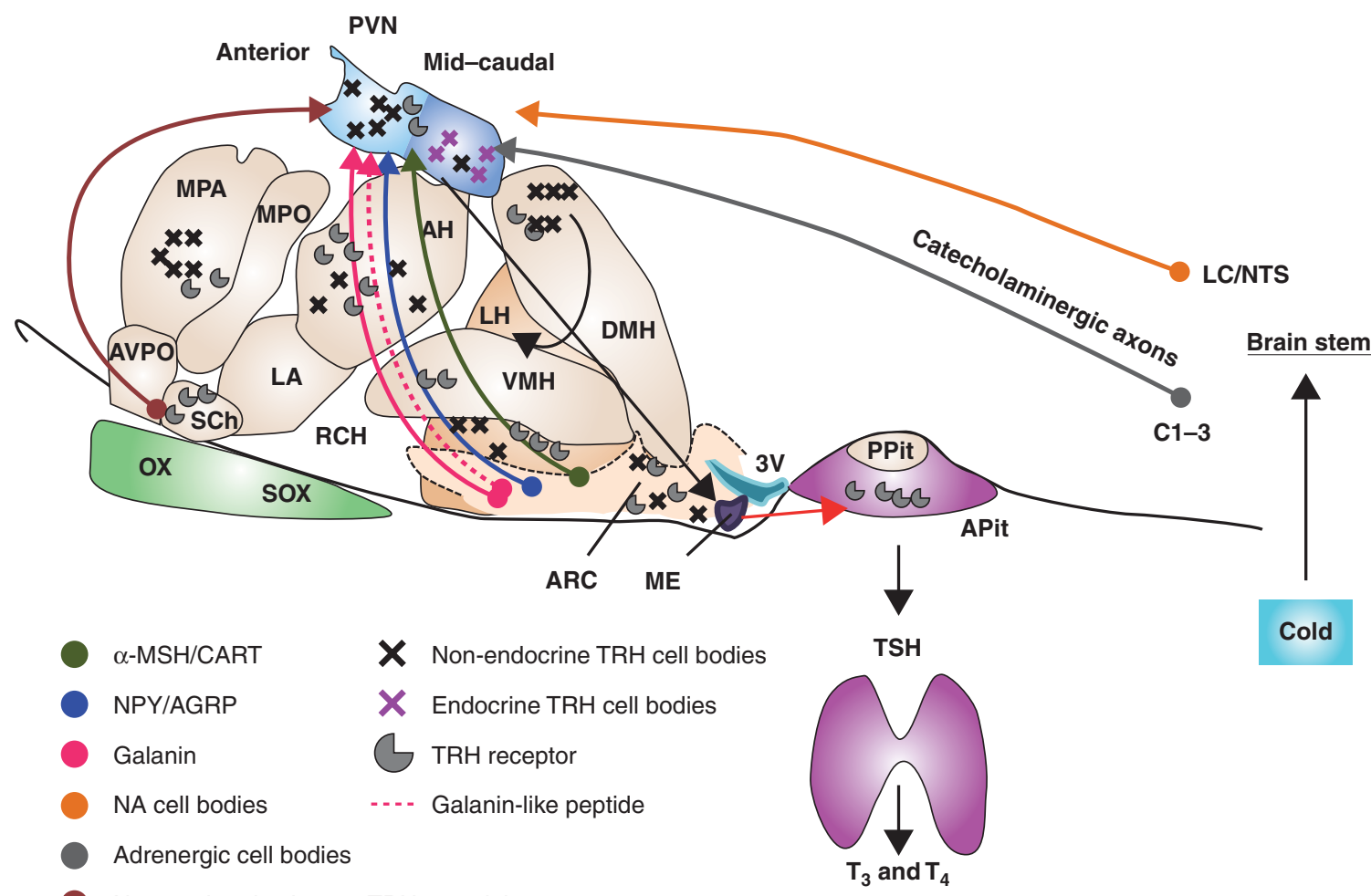

Neuronal projections to TRH-containing neurons

\section{Figure 1}

Schematic localization of TRH endocrine and nonendocrine cell bodies and TRH receptor fields in the hypothalamus and pituitary and of afferents to TRH neurons. TRH-synthesizing neurons in the rat PVN are represented in light purple, the anterior PVN and the mid-caudal PVN in dark purple. Arrows indicate afferents originating from the ARC and the brainstem that regulate the hypothalamic-pituitary-thyroid axis. AGRP co-localizes with NPY in the ARC (orexigenic peptides, blue arrow); NPY innervation to hypophysiotropic TRH neurons originates mainly from the ARC, and some (25\%) from the brainstem. Hypophysiotropic TRH neurons receive afferents from ARC neurons synthesizing anorexigenic peptides cocaine-amphetamine regulated transcript (CART)/ $\alpha$-MSH and CART expressed in adrenergic $\mathrm{C} 1-3$ regions in the medulla. ARC neurons expressing the orexigenic peptide galanin innervate the anterior PVN parvocellular subdivision (aPVN), mid and caudal PVN, and GALP only aPVN (pink arrows). Catecholaminergic inputs arising from the brainstem play a key role in regulation of the HPT axis in response to cold. Both noradrenergic

of TSH and its transcription and posttranslational modifications, such as glycosylation, that define the bioactivity of TSH (Chiamolera \& Wondisford 2009). Under certain physiological conditions, TRH modulates prolactin or growth hormone synthesis and release (Galas et al. 2009). The concentration of pituitary TRH-R1 is regulated by TRH and several other hormones (Chiamolera et al. 2012, Hinkle et al. 2012). Released TSH controls several steps of the synthesis of thyroid hormones $(\mathrm{TH})$ at the thyroid gland, increasing serum levels of thyroxine $\left(\mathrm{T}_{4}\right)$ and to a minor degree, 3,5,3'-triiodothyronine $\left(\mathrm{T}_{3}\right)$. Deiodinases 1 or $2(\mathrm{D} 1, \mathrm{D} 2)$ convert $\mathrm{T}_{4}$ to $\mathrm{T}_{3}$ in various
(LC and NTS, orange arrows) and adrenergic (C1-3 regions, brown arrow) axons establish contacts with TRH neurons in the PVN (Fekete \& Lechan 2014). AH, anterior hypothalamic area; $A R C$, arcuate hypothalamic nucleus; AVPO, anteroventral preoptic nucleus; $\mathrm{DMH}$, dorsomedial hypothalamic nucleus; GALP, galanin-like peptide; LA, lateroanterior hypothalamic nucleus; LC, locus coeruleus; $\mathrm{LH}$, lateral hypothalamic area; ME, median eminence; MPA, medial preoptic area; MPO, medial preoptic nucleus; NTS, nucleus solitary tract; OX, optic chiasm; Ppit, posterior lobe of pituitary; PVN, paraventricular hypothalamic nucleus; $\mathrm{RCH}$, retrochiasmatic area; SCh, suprachiasmatic nucleus; SOX, supraoptic decussation; $\mathrm{VMH}$, ventromedial hypothalamic nucleus; $3 \mathrm{~V}$, third ventricule. The figure is based on Paxinos \& Watson (2005) (The Rat Brain, 5th Edn): Fig. 78 (lateral $0.4 \mathrm{~mm}$ ) and coronal sections (Figs 24-33; Bregma -1.4/-3.8) to delineate approximate location of hypothalamic nuclei; PVN division in Simmons \& Swanson (2009)).

tissues and their activity is differentially regulated in a condition- and tissue-specific manner (McAninch \& Bianco 2014). TH have crucial roles in basal metabolic rate, thermogenesis, lipid and carbohydrate metabolism, indicating that the hypothalamus-pituitary-thyroid (HPT) axis is an important player in energy homeostasis (Hollenberg 2008, Fliers et al. 2014, McAninch \& Bianco 2014, Mullur et al. 2014).

The activity of the HPT axis is stringently regulated by neuronal stimuli impinging on TRH neurons and by the negative-feedback effects of TH on TRH and TSH synthesis and release (Hollenberg 2008, Fekete \& Lechan 2014,

Published by Bioscientifica Ltd 


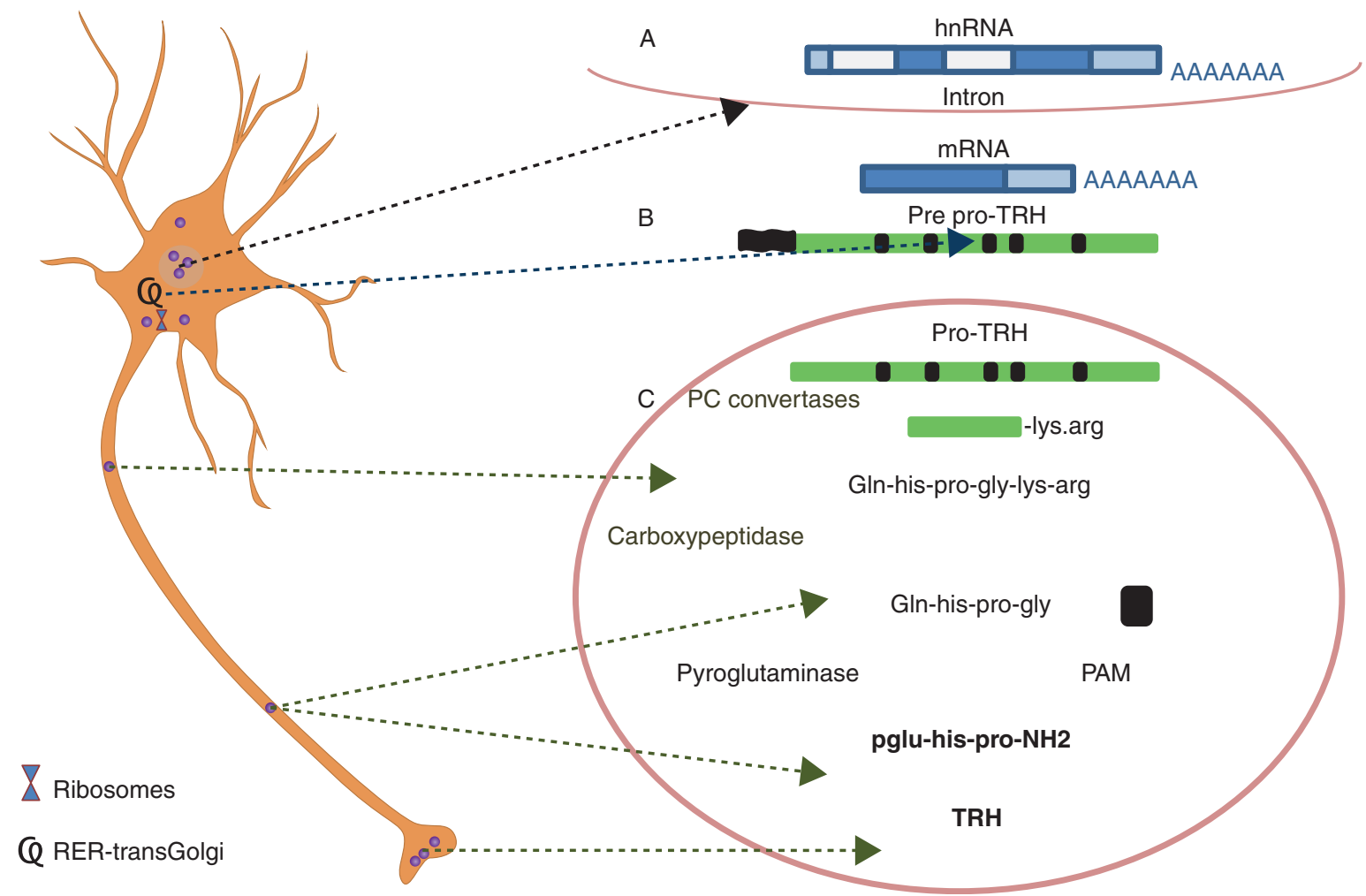

\section{Figure 2}

Schematic representation of TRH synthesis. (A) The primary transcript is synthesized in the nucleus as prepro-TRH heterogeneous nuclear RNA (hnRNA) which contains two introns and five exons. (B) After splicing, mature RNA is transported to the cytosol, binds to ribosomes, begins transcription of prepro-TRH mRNA, the leader sequence is cleaved, synthesis of pro-TRH continues with ribosomes linked to rough endoplasmic reticulum (RER) and precursor is transported inside the ER. (C) At the transGolgi pro-TRH may suffer a first cleavage by protein convertase 1 (PC1), proTRH is compartamentalized in secretory granules with the rest of

Fliers et al. 2014). $T_{3}$ downregulation of $T r h$ mRNA levels occurs specifically in the hypophysiotropic neurons of the PVN and not in other hypothalamic nuclei expressing Trh in rat or mouse (Segerson et al. 1987, Sugrue et al. 2010). The neuronal concentration of $T_{3}$ in the PVN is controlled by D2-conversion of $\mathrm{T}_{4}$ in tanycytes, the presence of $\mathrm{T}_{3}$ transporters, and the activity of neuronal $\mathrm{D} 3$ that inactivates $\mathrm{T}_{3}$, converting it to $\mathrm{rT}_{3}$ (Fliers et al. 2006, Fekete \& Lechan 2014). The most commonly used sensor of activation of TRH neurons has been the measurement of Trh mRNA levels. Rapid $(<2 \mathrm{~h})$ changes in TRH tissue concentration, mostly concentrated at nerve endings have been used as an indirect marker of TRH release because at later times TRH content represents the resultant of synthesis and release but not of degradation because the intracellular peptidases do not modulate TRH levels within secretory granules (Rondeel et al. 1991, processing enzymes: PCs cleave at the carboxy end of a pair of basic residues, a carboxypeptidase cleaves the basic residues leaving the immediate precursor of TRH: gln-his-progly (black squares) and cryptic peptides (green); pyroglutaminase converts gln to pyroglu and peptidylglycine- $\alpha$-amidase (PAM) leaves the amino group of the glycine bound to the carboxyl end (forming the amide group) and cleaves the rest of the procarbon moieties. Processing occurs as the secretory granule is transported to the nerve terminal (Nillni 2010).

van Haasteren et al. 1995, Charli et al. 1998, Aguilar-Valles et al. 2007).

\section{TRH biosynthesis}

The Trh gene encodes a protein that contains 5-8 (depending on the species, Wallis 2010) repetitions of the gln-his-pro-gly sequence (Lechan et al. 1986). Like other neuropeptides, the precursor ppTRH is synthesized in the neuronal soma at the endoplasmic reticulum (Fig. 2B) where it is cleaved to proTRH, compartmentalized at the transGolgi into secretory granules that travel together with processing enzymes to the nerve endings where most of TRH is found (Nillni 2010) (Fig. 2C).

Trh mRNA is transcribed from a unique gene (Fig. 2A); the proximal promoter equivalent to $250 \mathrm{bp}$ upstream of the TATA box contains several response elements (REs) that

Published by Bioscientifica Ltd. 
A Response elements in rat Trh proximal promoter

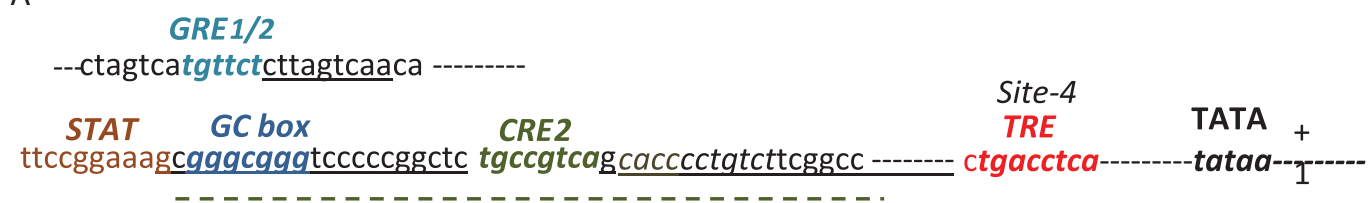

B Possitive regulation
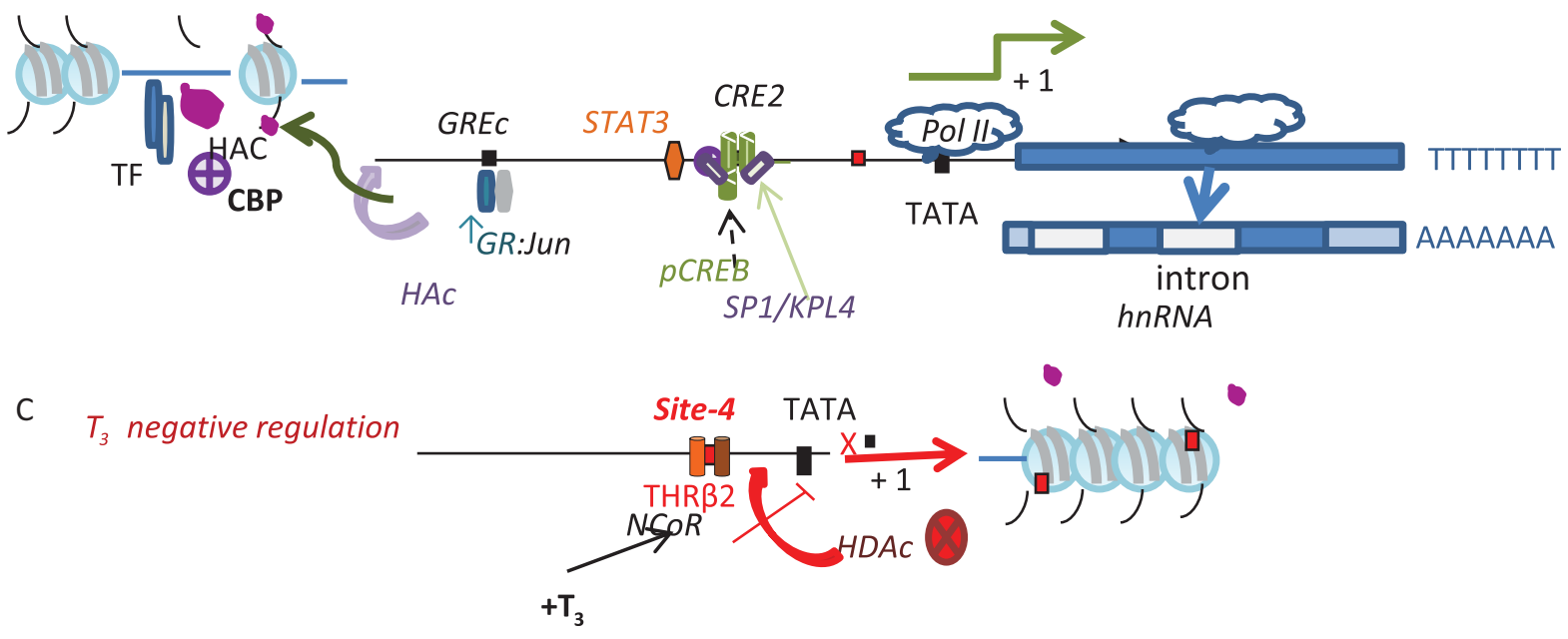

\section{Figure 3}

Sequences of response elements for transcription factors proven to be involved in regulating Trh transcription. (A) $T_{3}$ binds to thyroid hormone receptor THR $\beta$ on site 4 or THRE; corticosterone to GR-cJun on composite GRE (GRE1/2-AP1); leptin to STAT3, and pCREB on CRE; SP1 or KPL4 bind to extended CRE (green dashed line) (Lee et al. 1988, Díaz-Gallardo et al.2010a,b, Cote-Vélez et al. 2011). (B) Stimulation of transcription has been observed after treatment with noradrenaline, BDNF, and ERK, PKA activators that stimulate phosphorylation of CREB which binds to CRE; PKA activators also induce binding of SP1; PCREB recruits CBP with acetylase

provide binding sites for specific transcription factors (TFs) whose activity is modulated by various signals (Lee et al. 1988; Fig. 3A). Chromatin remodeling constitutes the first step in transcriptional regulation; recruitment of specific TF, coregulators, and histone acetylases loosens the DNA from histones allowing initiation of transcription by RNA polymerase II (Pol II; Fig. 3B); certain TFs recruit histone deacetylases that compact chromatin repressing transcription (Gadaleta \& Magnani 2014; Fig. 3C).

The negative regulation of TRH and TSH synthesis has long been recognized, but the mechanism is still under study (Segerson et al. 1987, Guissouma et al. 2000, Hollenberg 2008, Chiamolera et al. 2012, Vella et al. 2014). $T_{3}$ binds to TH receptors (THRs) THR $\alpha 1$, or THR $\beta 1$ and THR $\beta 2$, that are expressed and regulated in a tissuespecific manner; the same receptor may stimulate or inhibit transcription of multiple proteins in the same tissue (Ramadoss et al. 2014). The THR RE in the Trh activity that releases the complex of histones and chromatin allowing binding of polymerase II (Pol II) and transcription machinery to proceed with transcription. This mechanism may occur with other transcription factors that present stimulatory activity such as STAT3 or GR-cJun. (Díaz-Gallardo et al. 2010b, Cote-Vélez et al. 2011). (C) Transcriptional repression of Trh transcription may occur by $T_{3}$ binding to THR on site 4 , recruiting corepressors and deacetylases that compact chromatin avoiding binding of polymerase and basal transcriptional machinery (Hollenberg 2008, Díaz-Gallardo et al.2010a).

promoter (site 4, Fig. 3A) binds THRs as homo- or heterodimers with retinoid $\mathrm{X}$ receptors (RXRs) in vitro; in transiently transfected cells, unliganded receptors activate Trh transcription whereas repression requires $T_{3}$ to be bound to the receptor (Guissouma et al. 2000, Hollenberg 2008, Chiamolera \& Wondisford 2009; Fig. 4). Mice with knock-outs of the different THRs were used to demonstrate THR $\beta 2$ to be the most important receptor involved in downregulation of $T r h$ transcription by $\mathrm{T}_{3}$ (Abel et al. 2001, Chiamolera \& Wondisford 2009); however, transfection of Thr $\beta$-KO mice with either THR $\beta 1$ or THR $\beta 2$ rescues $\mathrm{T}_{3}$-induced TRH expression, but only THR $\beta 1$ is able to activate in a ligand-independent manner (Dupré et al. 2004). Chromatin immunoprecipitation (ChIP) from stably transfected GH4C1 cells with Trh promoter detects acetylated histones 3 and 4, THR $\beta$, and bound Pol II; $\mathrm{T}_{3}$ treatment transiently recruits deacetylases (HDAC2, 3), diminishes Pol II binding and, after $24 \mathrm{~h}$, also THR $\beta$

Published by Bioscientifica Ltd. 


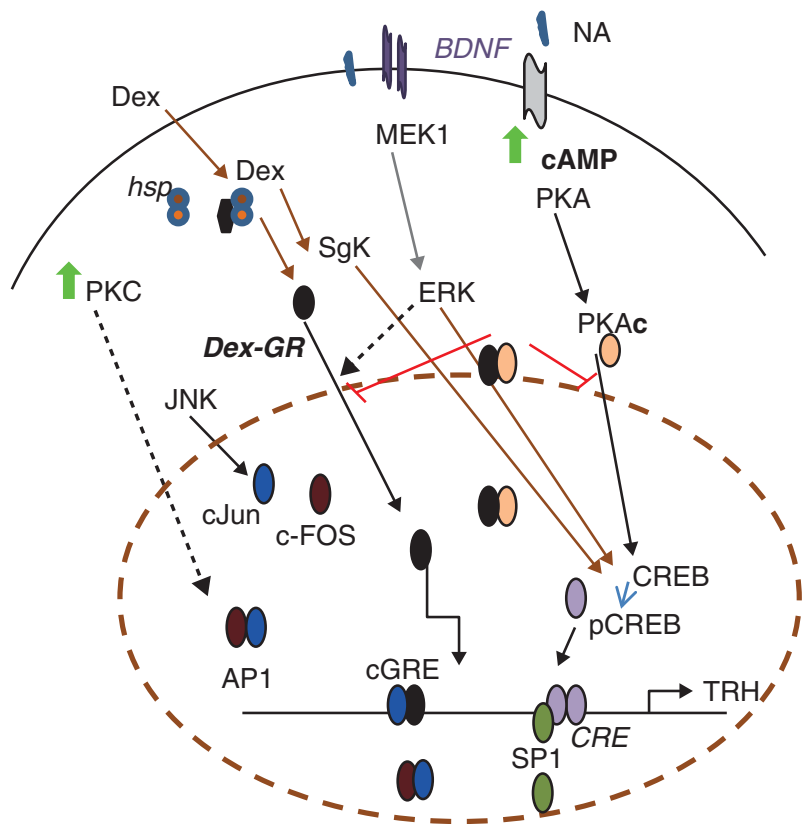

Figure 4

Model of rapid regulation of $T r h$ transcription by extracellular signals. The transcription of the pro-TRH gene is rapidly increased by activators of CREB phosphorylation and by glucocorticoids. Noradrenaline (NA), BDNF, and dexamethasone or corticosterone, through protein kinase A (PKA), the ERKs MEK/ERK, and serum-glucocorticoid kinase (SgK), induce the phosphorylation of CREB; pCREB enhances transcription through an interaction with the CRE2 site. Activation of the glucocorticoid receptor (GR) by ligand binding releases it from a multiprotein complex; it is phosphorylated and transported to the nucleus where the GR:Jun heterodimer binds to a composite GRE (cGRE). A cross talk between the two pathways alters the individual transcriptional responses; glucocorticoids interfere with PKA stimulation of Trh transcription by a protein-protein interaction that impedes binding of pCREB or GR to their REs (Cote-Vélez et al. 2008, 2011, Díaz-Gallardo et al. $2010 \mathrm{~b}$ and references therein).

(Umezawa et al. 2009). THRß2 binds to the Trh proximal promoter region of chromatin from hypothalamic cells incubated $1 \mathrm{~h}$ with $\mathrm{T}_{3}$ (Díaz-Gallardo et al. 2010a), as well as deacetylase (HDAC3), whereas Pol II and histone acetylases diminish compared with controls (Sotelo-Rivera et al. 2012). Chromatin from hypothalami of newborns has THR $\beta$ or RXR bound to TRH promoter which decreases after $20 \mathrm{~h}$ of $\mathrm{T}_{3}$ treatment (Decherf et al. 2013). These results support the hypothesis that $\mathrm{T}_{3}-\mathrm{THR} \beta$ recruitment of deacetylases that may compact chromatin and inhibit Pol II binding and Trh transcription (Fig. 3C). Whether THR $\beta$ remains bound to DNA in vivo after longer $\mathrm{T}_{3}$-treatments awaits resolution (Ramadoss et al. 2014).

Neuronal stimulation activates kinases such as PKA, PKC, and MAPK/ERK that rapidly enhance Trh transcription or mRNA levels in several cell systems (Uribe et al. 1995a, Pérez-Martínez et al. 1998, Harris et al. 2001, Cote-Vélez et al. 2005 , 2008). The Trh proximal promoter contains a
phosphorylated-CREB (pCREB) binding site (CRE2: positions $-101 /-92$ in rat) that is protected, along with adjacent $5^{\prime}$ GC box and $3^{\prime}$ CACC sequences, by nuclear extracts of cAMP-stimulated hypothalamic cells (Fig. 3A; Díaz-Gallardo et al. 2010a,b); these adjacent sites are recognized by SP1/Krüppel-like factors (Kpl; Ren et al. 1998, Díaz-Gallardo et al. 2010b, Pérez-Monter et al. 2011). Deleted or mutated CRE2 or CACC sites resulted in a decrease of $50-80 \%$ in basal and $50 \%$ in forskolin-induced transcription (the latter also with mutated GC box; Cote-Vélez et al. 2011). Multiple-intracellular signals phosphorylate CREB in the nucleus, pCREB binds to its REs and interacts with coactivators (some with histone-acetylase activity) increasing transcription (Fig. 3B; Altarejos \& Montminy 2011). SP1 binding may increase the stability of pCREB on CRE2, as has been proposed for a nonconical sequence (Lundblad et al. 1998) or, depending on the TF of the SP/KPl family, cause interference. ChIP assays revealed other REs, such as the STAT-binding site, responsive to leptin stimulation (Guo et al. 2004). A composite glucocorticoid RE (cGRE), formed from a half-site GRE next to an AP1 RE, binds the glucocorticoid receptor (GR) as a heterodimer with cJun after dexamethasone stimulation (Cote-Vélez et al. 2005, Díaz-Gallardo et al. 2010b; Fig. 3A).

\section{Caveats regarding biosynthesis studies}

Before continuing with this review we would like to stress some problems worthy of consideration when studying the regulation of TRH biosynthesis, given the diversity of experimental paradigms used. Cell lines are homogenous but with a particular set up that differs from the physiological situation, they are usually incubated with drugs for long periods and under steady conditions in contrast to in vivo situations where events such as clearance and diffusion play important roles. Transient transfections omit the regulatory steps related to chromatin remodeling (Gadaleta \& Magnani 2014). Primary culture of embryonic hypothalamic cells (Uribe et al. 1995a, Harris et al. 2001), or transfected hypothalami of newborn pups (Guissouma et al. 2000), involve a mixture of multiple hypothalamic nuclei whose developmental windows, afferents and receptors, might differ to those exclusive to the PVN; furthermore, they miss the developmental effects of gonadal hormones (McCutcheon \& Marinelli 2009). Knockout animals provide important information (Supplementary Table 1, see section on supplementary data given at the end of this article), but early-compensatory responses may lead to altered homeostatic states and/or the animals may have phenotypes that result from the simultaneous

Published by Bioscientifica Ltd 
manipulation of many organs that contribute, for example, to altered TH levels (Astapova \& Hollenberg 2013); however, they revealed the redundancy of important regulatory molecules (Chiappini et al. 2013). Notwithstanding the problems mentioned, these distinct approaches have provided important information for identifying potential modes of Trh transcriptional regulation.

\section{The HPT axis in energy balance}

Circuits involved in energy balance overlap with those involved in food intake. Afferents from neurons of the brain stem or of the arcuate nucleus (ARC) convey nutritional information to the PVN and other hypothalamic nuclei. ARC neurons detect circulating hormones levels modulated by the nutritional and energy status (ghrelin, leptin, insulin, glucose, and fatty acids) and activate or inhibit neurons that express orexigenic (neuropeptide Y (NPY) and agouti-related peptide (AgRP)) or anorexigenic (pro-opiomelanocortin (POMC) and cocaine amphetamine-regulated transcript (CART) peptides) (Schneeberger et al. 2014); Trh expression is inhibited by orexigenic and stimulated by anorexigenic peptides (Fekete \& Lechan 2014). Table 1 summarizes data on mRNA levels of Trh and several ARC peptides, as well as on serum hormones in rodents studied under different paradigms. Caution is required to distinguish measurements in the hypophysiotropic area (approximately 50\% of parvicellular PVN neurons (Simmons \& Swanson 2009)) normally determined by in situ hybridization (ISH) of Trh mRNA in mid-caudal PVN, against total PVN by analysis in dissected tissue (Fig. 1; Fekete \& Lechan 2014).

TRH-hypophysiotropic neurons are the central integrator of the HPT axis, considered to be metabolic sensors as they decode neuronal and hormonal signals related to the energy status (Lechan \& Fekete 2006, Hollenberg 2008). THs have multiple targets responsible for energy distribution and expenditure (Klieverik et al. 2009, Mullur et al. 2014). Negative energy balance such as fasting, food restriction, or pathological situations, including infection or critical illness, decreases serum levels of TH, and TSH to some extent, as well as of Trh expression in hypophysiotropic TRH neurons. In humans, these conditions are recognized as nonthyroidal illness syndrome (NTIS). The principal mechanism of fasting-induced decreased Trh expression involves a drop in leptin serum concentrations that lowers $\alpha$-MSH and CART stimulatory tone, and enhances the inhibitory effect of NPY/AgRP on TRHergic neurons (Fekete \& Lechan 2014). Results from animal models of infection or inflammation support the hypothesis that the mechanism causing NTIS primarily entails increased D2 activity in tanycytes and reduced D1 and D3 in liver and muscle, changes probably produced by cytokines and not by corticosterone (Fekete \& Lechan 2014, Fliers et al. 2014). The effects are more pronounced in chronic situations where multiple factors intervene, including feeding status. In humans, postmortem analyses of critically ill patients showed low $\mathrm{T}_{4}$ and $\mathrm{T}_{3}$ liver concentrations and reduced TRH mRNA expression, supporting inhibition of the HPT axis at central level (Fliers et al. 2014).

The effects of energy excess on TRHergic neurons are less clear. Body-weight gain (approximately 20\%) induced by high-fat diet (HFD), or ovariectomy, is associated with increases in Trh expression in the PVN; both conditions augment circulating leptin levels, although only HFD increases TH serum concentrations in rat (Perello et al. 2010). Leptin rapidly activates TRHergic neurons, indirectly in mid-PVN through its effects on ARC neurons and directly in caudal-PVN with high concentration of leptin receptors (Huo et al. 2004, Perello et al. 2006). Leptin's direct effect is further supported by the exclusive increase in Trh mRNA in caudal PVN of ovariectomized rats (Uribe et al. 2009). The response of TRHergic neurons to feeding conditions differs in obese and lean rodents (Perello et al. 2010); under basal conditions Trh mRNA levels in the PVN are similar in obese and in lean Zucker rats; however, fasting decreases Trh expression more drastically in obese rats than in lean rats, a difference overridden by adrenalectomy (Duclos et al. 2005). A different allostatic state in obesity, related to a particular state of receptors causing leptin or insulin resistance, could be the basis of these differences.

Events involved in the regulation of energy balance such as fat metabolism, thermogenesis, body weight, food intake, and fat distribution is sex-dependent. Estrogen modulates the expression of several orexigenic and anorexigenic peptides and hormones (Brown \& Clegg 2010). Male rats are more sensitive to insulin and females to leptin; compared with males, females adapt more efficiently to energy deficits, are more susceptible to HPT inhibition by food restriction, have lower pituitary expression of TSH $\beta$ and serum TSH associated with higher levels of $\mathrm{T}_{3}$, and reduced hepatic activity of D1 under basal conditions (Cizza et al. 1996, van Haasteren et al. 1996, Valle et al. 2005, Marassi et al. 2007). Estrogen stimulates thyroid function, increasing iodide uptake and thyroid peroxidase activity which would increase TH biosynthesis (Lima et al. 2006). The expression of Trh in the PVN varies during the estrous cycle with highest levels at diestrous 2

Published by Bioscientifica Ltd. 


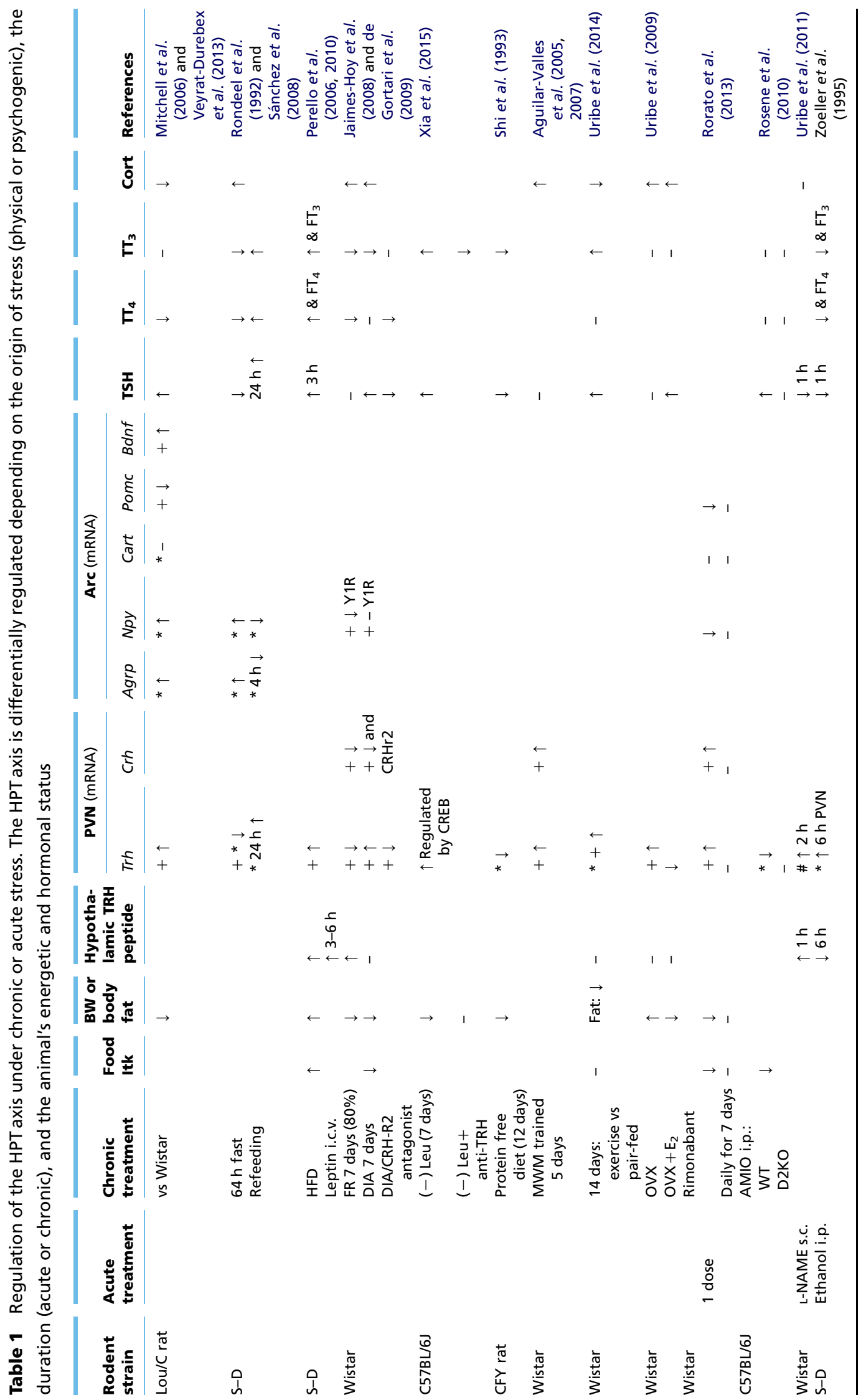




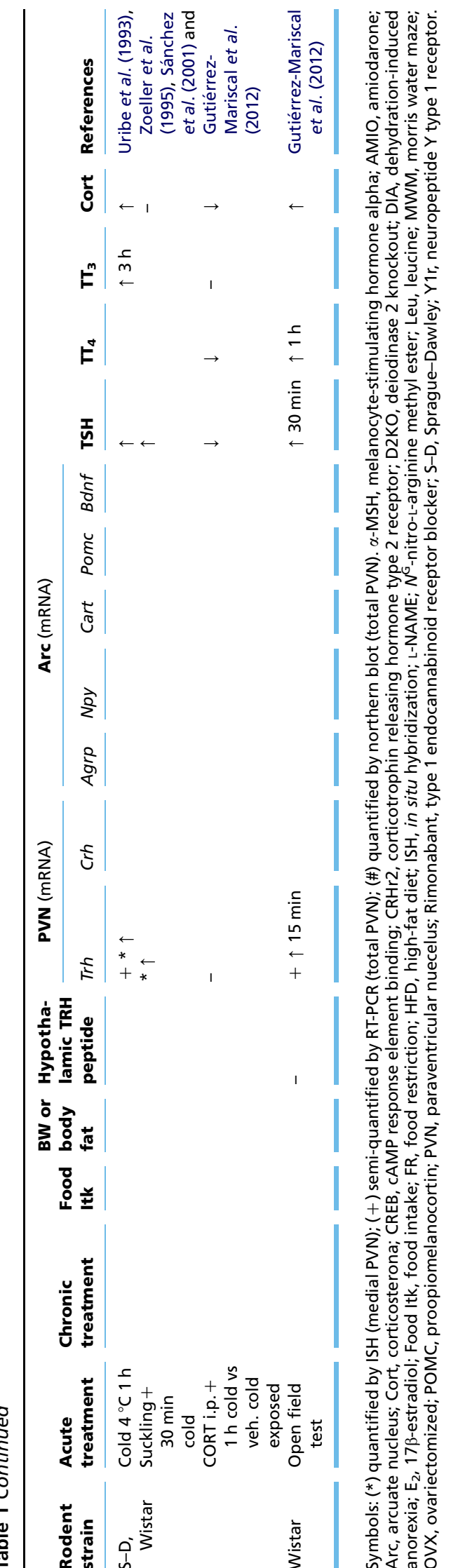

http://joe.endocrinology-journals.org DOI: $10.1530 / J O E-14-0593$
(C) 2015 Society for Endocrinology Printed in Great Britain
(Uribe et al. 1991). However, the effects of estrogen and the consequences of ovariectomy on serum TH and TSH concentrations are controversial and depend on the paradigm studied and age and previous gonadal status (Lima et al. 2006, Marassi et al. 2007, Uribe et al. 2009). Consistent with role of TRH in prolactin secretion, Trh mRNA levels increase, parallel to prolactin serum concentration, during the lactation period and in response to suckling (Uribe et al. 1993). As lactation progresses, levels of Trh mRNA decrease whereas those of prolactin rise; removal of pups normalizes Trh mRNA expression proportional to weaning time and inversely proportional to serum corticosterone levels (Uribe et al. 1991, 1995b).

\section{Stress and the HPT axis}

Stress was defined by Selye as the nonspecific response of the body to any demand (Selye 1976). This definition has been revised (Koolhaas et al. 2011). The type of stress defines the nature of the response; physiological (systemic) stressors such as cold, pain, and disease involve neuronal circuits that usually decode stimuli at the level of the brain stem, whereas psychogenic stressors are motivated by previous experiences and involve limbic areas such as the amygdala, hippocampus, and frontal cortex; all directly or indirectly converge at the PVN and activate the sympathetic nervous system and the hypothalamuspituitary-adrenal (HPA) axis (de Kloet 2014, Myers et al. 2014). The response of the HPA axis is characterized by increased synthesis and release of corticotrophin-releasing hormone (CRH) from the PVN, adrenocorticotrophin hormone from the pituitary, and glucocorticoids (GCs) from the adrenal cortex. In rodents, paradigms of psychogenic stressors include restraint, chronic defeat stress, or isolation; their responses differ according to the controllability of the stressor, whether the animal senses a previously encountered stressor (homotypic) that causes habituation or a new one (heterotypic) to which a hyperreaction may occur (Koolhaas et al. 2011, Myers et al. 2014).

Stress, whether chronic or acute, modifies eating patterns and metabolism, and is considered to be at the base of the metabolic syndrome (Charmandari et al. 2005, Maniam \& Morris 2012). GC excess or deficiency leads to several metabolic problems (Rose \& Herzig 2013). As these hormones act in multiple organs, it is difficult to distinguish direct effects from indirect effects in paradigms such as adrenalectomy or thyroidectomy and hormone replacement. Chronic stress may increase or decrease food intake in humans whereas in animals this usually diminishes unless they are offered a

Published by Bioscientifica Ltd 
palatable food, although abdominal adiposity increases (Dallman et al. 2007). Chronic GC administration increases Npy and Agrp expression, the activity of their synthesizing neurons, alters the melanocortin system; and increases food intake; it causes multiple metabolic changes such as insulin resistance, visceral fat accumulation, high serum leptin levels (Dallman et al. 2007, Maniam \& Morris 2012) and decreased Trh expression in the PVN and TSH serum concentrations in rat and in human (Kakucska et al. 1995, Alkemade et al. 2005). The GC-induced increase in NPY expression could contribute to GC-inhibitory effect on Trh mRNA levels in the PVN. Patients with Cushing's disease present hypothyroidism and Trh expression in the PVN is reduced in postmortem brains of patients that received GC treatment or suffered major depression (Alkemade et al. 2005).

Various forms of long-term psychogenic stress decrease TSH and TH serum levels in rats (Armario \& Castellanos 1984, Servatius et al. 2000), but reports on Trh expression are scarce. Constriction injury of sciatic nerve decreases Trh mRNA levels in the whole hypothalamus as well as serum TH levels (Kilburn-Watt et al. 2010). Foot shock (14 sessions/day) decreases total and free $\mathrm{T}_{4}$ and $\mathrm{T}_{3}$ serum concentrations without affecting Trh in the PVN, whereas Agrp mRNA levels in the ARC increase (Helmreich et al. 2005); a milder form of stress, such as 60 min daily restraint for 2 weeks, does not affect Trh mRNA expression in the PVN nor TSH or TH serum levels (Uribe et al. 2014). The intensity of the stressors thus seems to determine HPT activity and Trh expression; however, despite significant changes not being observed in the latter two paradigms, levels of $\operatorname{Trh}$ mRNA correlate negatively with those of corticosterone and positively, with body-weight changes.

Situations of increased energy expenditure such as exercise and cold are also considered stressful. Cold exposure rapidly activates the autonomic nervous system and the HPT and the HPA axes. Thermogenesis is achieved primarily by the activity of brown adipose tissue (BAT) and the uncoupling proteins through adrenergic stimulation in concert with TH and lipolysis (Mullur et al. 2014). Three-day cold exposure of rats increases BAT D2 and its thermogenic activity, D2 increases in skeletal muscle after 10 days and, total and free $T_{3}$ increase whereas total $T_{4}$ decreases at both times, indicating increased peripheral TH conversion (Louzada et al. 2014). Whether long-term cold exposure is constant or intermittent, the metabolic and behavioral effects (increased food intake or physical activity) vary because adaptive changes occur, although data on the effects of chronic cold exposure on TRH expression are lacking and changes in TSH or TH serum levels depend on the condition studied (Silva 2011, Yoo et al. 2014). Human beings adapt to prolonged exposure to a cold environment by increasing metabolic and physiologic responses; after moving to the Antartic, energy requirements increase, as well as $T_{3}$ production, clearance and distribution, TRH-stimulated TSH release, TSH and thyroglobulin serum levels, while altered total and free TH levels may depend on altitude differences (Palinkas et al. 2007). When exposed for $60 \mathrm{~h}$ to $50 \%$ energy restriction, humans loose considerable body weight but do not decrease $\mathrm{TH}$ or TSH serum levels as in temperate conditions, which indicates that cold stimulation overcomes the inhibition produced by food restriction (Case et al. 2006).

Exercise is proposed to be a chronic stressor that inhibits HPT and activates HPA axes (Mastorakos \& Pavlatou 2005). This depends on the type of exercise, i.e. extenuating or forced versus voluntary (as wheel running; Steinacker et al. 2005, Stranahan et al. 2008). Compared with naïve sedentary controls, 2-week voluntary running reduces food ingestion (18\%); the decreased energy intake in the sedentary pair-fed group causes similar changes to those caused by $40 \%$ food restriction for 25 days in rats, decreased levels of serum leptin, $\mathrm{TSH}_{\mathrm{H}} \mathrm{T}_{3}$, BAT-D2, and liver-D1 activities, and increased corticosterone (Araujo et al. 2009). Exercise blunted several of the changes produced by the $18 \%$ reduced food intake, i.e. $\mathrm{Trh}$ diminished $30 \%$ instead of the $50 \%$ seen in the pair-fed rats, and neither $\mathrm{T}_{3}$ or deiodinases activities were altered; however, white adipose tissue (WAT) mass diminished in exercised rats whose serum leptin concentration decreased much more than that of the pair-fed rats; furthermore, the amount of exercise performed correlated positively with $\mathrm{T}_{3}$ and Trh mRNA levels and negatively with WAT mass (Uribe et al. 2014). Exercise thus overrides the signals of energy deficiency, such as low serum leptin concentration; the intermittent activation of PVN-TRH neurons and of TH release (seen after an acute increase in physical activity, see below) may guarantee maintenance of TH levels for adequate fuel supply to oxidizing tissues, such as released fatty acids from WAT (Klieverik et al. 2009, Weber 2011). Hypophysiotropic TRHergic neurons may therefore be included in a central homeostatic circuit modulated by exercise, which by maintaining adequate TH-induced lipolysis or serum glucose levels through PVN-sympathetic and parasympathetic hepatic activity guarantee energy supply to metabolic tissues (Fliers et al. 2014).

TRH expression in the hypophysiotropic neuron at a given time depends thus on the concentration of $\mathrm{T}_{3}$, THR and co-regulators, nutritional status, stress history, and the extent of neuronal and hormonal influences that sense the

Published by Bioscientifica Ltd 
'basal' state of the organism and regulate TRH synthesis and release - a process further modified by the environmental influences it must contend with. The HPT axis is inhibited in response to energy deficits or chronic stress. However, animals submitted to energy-demanding situations, such as chronic cold or exercise, have altered HPT axis activity and may present high or normal circulating levels of $\mathrm{TH}$, although Trh expression in the PVN and serum TSH levels may be differentially affected (Table 1 ).

\section{HPT responses to acute stimuli}

Several neuromodulators regulate the excitability of TRHergic neurons of the PVN; NPY inhibits neuronal activity whereas $\alpha$-MSH and leptin stimulates it, effects consistent with the known responses on $\mathrm{TSH}$ or $\mathrm{T}_{4}$ release (Ghamari-Langroudi et al. 2010). GCs rapidly suppress glutamatergic excitatory inputs onto various parvicellular neurons of the PVN, including those expressing TRH; the effect is mediated through membrane receptors, whose activation causes the release of endocannabinoids that act at the presynaptic side to inhibit glutamate release (Di et al. 2003). TRH neurons in the PVN receive afferents from the suprachiasmatic nucleus that modulate TRH expression in a circadian manner (Kalsbeek et al. 2000, Zoeller et al. 1990).

Acute stress inhibits the HPT axis at different levels; $1 \mathrm{~h}$ restraint or $2 \mathrm{~h}$ immobilization decrease Trh mRNA expression in the rat PVN together with TRH and TSH release during the following hour; the response to immobilization is higher in female rats (Cizza et al. 1996, Gutiérrez-Mariscal et al. 2012). However, a stressful condition, such as the defensive burying test that involves increased physical activity (burying), augments the levels of Trh mRNA in the PVN but not TSH release (GutiérrezMariscal et al. 2008). Situations of energy demand, such as physical activity or cold exposure, cause an immediate response of the HPT and the HPA axes. TH and GCs are rapidly released; the latter mobilize glucose for fast responses and the former activate fuel distribution to oxidizing tissues (Klieverik et al. 2009, Rose \& Herzig 2013). This is coupled with changes in TRH biosynthesis. For example, physical activity in the open field increases the expression of Trh in the PVN accompanied by enhanced TRH and TSH release, but only if animals are tested during the dark period. The stress response is stronger in animals tested during the light hours when the HPT response is blunted (Gutiérrez-Mariscal et al. 2012). Another type of exercise, such as swimming in a water maze, activates the HPT, increasing the expression of
Trh mRNA in the PVN and the release of TSH; the response of the HPT is opposite to the degree of stress induced by the test (Aguilar-Valles et al. 2005, 2007).

In response to a cold stress, catecholaminergic afferents from the brain stem onto the PVN rapidly contribute to increase $\mathrm{Crh}$ and $\mathrm{Trh}$ mRNA levels in the PVN, concomitant with the release of TRH, TSH, and corticosterone (Zoeller et al. 1990, 1995, Rondeel et al. 1991, Uribe et al. 1993). The changes in Trh mRNA are transient, with increases at $1 \mathrm{~h}$ and normalizing by $2 \mathrm{~h}$, even when animals are kept in the cold for long periods; Trh mRNA levels rise again at $6 \mathrm{~h}$ but only if animals are exposed during the light period (Uribe et al. 1993, Zoeller et al. 1995). Acute administration of some drugs alters Trh expression and these changes do not always coincide with changes in TSH or TH serum concentrations (Table 1). Although ethanol increases Trh mRNA levels in the PVN, it blocks increases induced by cold-exposure (Zoeller et al. 1995). Cold increases Trh mRNA expression independent of high-TH serum levels (Zoeller et al. 1990), but a mild stress $2 \mathrm{~h}$ before being submitted to cold suppresses the expected increase in Trh mRNA levels in the PVN but not in serum TSH in male rats (Uribe et al. 2011).

Cold exposure activates the HPT axis more in nonlactating female rats than in males or lactating females (Sánchez et al. 2001). Ovariectomized rats with increased body weight and high leptin serum concentration respond to cold stimulation augmenting Trh mRNA levels in the PVN, but the effect is suppressed by high doses of $17 \beta$-estradiol, while serum TSH and corticosterone levels are similar to those found in the ovariectomized animals (Uribe et al. 2009). In contrast, food-restricted female rats display greater increases in Trh mRNA levels in the PVN than controls after cold exposure, but TSH response is blunted (Jaimes-Hoy et al. 2008). These results exemplify situations in which the response to a life-threatening situation such as cold exposure is altered by stress, corticosterone, sex, and other as yet unidentified effectors.

As mentioned, TRH is involved in prolactin release during lactation (Galas et al. 2009), and the levels of TRH mRNA increase in mid-PVN $30 \mathrm{~min}$ after initiation of suckling (Sánchez et al. 2001). TRH hypophysiotropic neurons co-express CART, which is also induced after $1 \mathrm{~h}$ of cold exposure (Sánchez et al. 2007) but not after suckling. Since CART inhibits prolactin release in vitro and cold exposure does not induce the release of prolactin, CART may serve as a co-modulator of TRH in this physiological circumstance, stimulating TRH and TSH release while blocking prolactin release (Sánchez et al. 2001, 2007, Raptis et al. 2004).

Published by Bioscientifica Ltd. 
Because GCs affect not only the electrical activity of PVN-TRH neurons, but potentially the expression of Trh in rodents and humans, it is relevant to understand how they interact with the stimuli that control the HPT axis. The timing of GR activation is of utmost importance; GR is released from a cytosolic multi-protein complex upon ligand binding, phosphorylated, and translocated to the nucleus within minutes, where it acts as a transcription factor. The dynamics of GR transport and its half life depend on the presence of ligand, DNA binding, and activity of several kinases (Ratman et al. 2013, de Kloet 2014). The response of PVN Crh expression to restraint is blunted if animals receive corticosterone $1 \mathrm{~h}$ but not $3 \mathrm{~h}$ previously, supporting the relevance of timing of GR activation; in contrast, the increase in c-FOS due to restraint is not diminished by corticosterone pretreatment (Osterlund \& Spencer 2011). Trh mRNA levels in the PVN correlate negatively with corticosterone serum concentrations in animals under several circumstances; therefore, we studied the effect of a peripheral corticosterone injection on cold-induced Trh expression in the PVN. In male rats kept at room temperature, Trh mRNA expression is enhanced (greater than threefold) $2 \mathrm{~h}$ after corticosterone injection in the mid- and caudal-PVN, where TRHergic neurons co-express GR (Cintra et al. 1990). Rats that received injections of vehicle responded to cold as expected, increasing Trh mRNA levels in the three zones of the PVN and TSH serum concentration; however, in corticosterone pre-treated rats, Trh expression does not increase further after cold exposure and the response of TSH is suppressed (Sotelo-Rivera et al. 2014). GCs may inhibit TRH or TSH release directly at the median eminence or the pituitary respectively (van Haasteren et al. 1995, John et al. 2003). TRH synthesis and release might be uncoupled in those circumstances when TSH is not increased within an hour of exposure.

The interference of corticosterone with the coldinduced activation of Trh synthesis may be due to a cross talk between activated GR and elements of the PKA pathway, as demonstrated in vitro. Hypothalamic cells co-stimulated with dexamethasone and forskolin do not display increased Trh mRNA levels as are detected when they are incubated separately with each drug (PérezMartínez et al. 1998, Cote-Vélez et al. 2005), nor the recruitment of pCREB, GR, or Pol II to the Trh promoter (Díaz-Gallardo et al. 2010b). The effect is probably due to GR-PKA protein-protein interaction with PKA impeding CREB phosphorylation and GR binding to DNA (SoteloRivera et al. 2012). Similar cross talk between the PKA and GR intracellular pathways is detected also in cell lines, supporting the hypothesis that the effect is an intracellular event, and not due to the average of differential responses of TRHergic cells from different hypothalamic nuclei present in primary cultures (Cote-Vélez et al. 2005). The interference of GCs with the cAMP-stimulatory effect on Trh expression is avoided with inhibitors of the ERK/MAPK pathways (Cote-Vélez et al. 2008). These results, although obtained in vitro, support the possibility of fast cross talk between signaling pathways that may alter an immediate response (Fig. 2).

As mentioned in the previous section, long-term energy-demanding situations do not seem to keep the HPT axis activated, but the response to acute stimuli may prevail or be modified. One may envisage situations when TRH neurons are activated, TRH synthesis increases and simultaneously processed TRH is released, TSH secretion follows, causing $\mathrm{TH}$ release that modulates different metabolic reactions at target organs. The feedback effect includes not only TH at TRH or TSH synthesis, but molecules of the target tissues, GCs if HPA is co-stimulated and $\mathrm{TH}$ acting on other brain areas involved in the required circuit. TH affects metabolism acting at various hypothalamic nuclei increasing, for example, glucose production, modulating central autonomic outflow, and eating behavior or stimulating the dorso-medial hypothalamus (DMH) which activates the sympatheticBAT response involved in thermogenesis (Fliers et al. 2014).

TRHergic neurons may thus respond transiently to energy-demanding situations and maintain energy homeostasis. However, stress could impede a fast and efficient response of the HPT axis in which, for example, in cases such as cold exposure or increased physical activity, the lack of opportune lipolysis needed for fuel supply may oblige the organism to display alternative responses, such as increased food intake and decreased activity due to fatigue, thus contributing to the metabolic syndrome.

\section{Hypothalamic TRH neuronal populations}

In mammals, various brain circuits contribute to maintenance of energy balance (Schneeberger et al. 2014). Central administration of TRH or TRH agonists consistently reduces food intake in normal rodents and hungry rats, and in models of stress-induced feeding increases thermogenesis and arousal (Lechan \& Fekete 2006, Akieda-Asai et al. 2014). These effects may involve various hypothalamic targets because, for example, local injection of TRH into medial and lateral hypothalamus (LH) reduces feeding in rats (Suzuki et al. 1982) whereas administration into the preoptic area, dorsomedial, or ventromedial

Published by Bioscientifica Ltd. 
hypothalamus (VMH) increases BAT temperature in hamsters (Shintani et al. 2005). ISH of ppTRH mRNA, its receptors (TRH-R1 and TRH-R2), and inactivating enzyme (PPII) together with immunostaining of Trh and of TRH, as well as autoradiography of TRH binding sites, has been used to generate maps of brain TRHergic neurons, receptors, and inactivation sites (Vargas et al. 1987, Hökfelt et al. 1989, Lechan \& Segerson 1989, Heuer et al. 2000). However, the circuits in which they are involved are currently poorly understood as few of the projection fields of the TRH neurons have been identified with anterograde and retrograde techniques (Simmons \& Swanson 2009, Wittmann et al. 2009a,b, Fekete \& Lechan 2014). Understanding the role of hypothalamic TRHergic neurons (Fig. 1) requires consideration of their distribution because various regions, such as the LH, PVN, preoptic, suprachiasmatic, and dorsomedial nuclei express Trh mRNA (Fig. 1). The physiological state of TRH neurons has been evaluated by few electrophysiological studies on identified neurons and by biochemical markers of activation, such as detection of immediate early genes, or of TRH biosynthesis, but the output of TRH neurons is difficult to obtain in vivo because of sampling or sensitivity issues.

Even in a single nucleus, TRH neurons are not homogeneous. In the rat PVN, TRH-expressing neurons are distributed along the rostro-caudal part of the parvocellular and some in the magnocellular subdivisions (Fekete \& Lechan 2014). Almost half of the total PVN-TRHergic cells in the parvocellular part of the PVN are non-neuroendocrine or preautonomic, concentrated in the rostral or anterior PVN (aPVN) in the rat, with only few present in the mid-PVN and even fewer in the caudal. As mentioned, the hypophysiotropic or endocrine cells are concentrated in mid- and caudal-PVN (Simmons \& Swanson 2009, Fekete \& Lechan 2014). In mouse PVN, $69 \%$ of TRHergic endocrine cells project to the median eminence, while $17 \%$ project to the neurohypophysis, and the rest are non-endocrine cells localized in the anterior zone (Ghamari-Langroudi et al. 2010, Kádár et al. 2010). PVN-TRHergic neurons differ not only in their afferents, projections, and receptor expression (Fekete \& Lechan 2014) but also according to time of birth; rat non-neuroendocrine neurons peak at embryonic days 11-12 and neuroendocrine neurons at days 12-14 (Markakis \& Swanson 1997).

The non-neuroendocrine TRHergic neurons of the rat aPVN receive a robust innervation from NPY/AgRP and $\alpha$-MSH/CART neurons from the ARC (Fekete \& Lechan 2014) and from adrenergic and noradrenergic fibers from the brain stem (Füzesi et al. 2009). The $\alpha$-MSH input seems to be functional since central administration of $\alpha$-MSH enhances the phosphorylation of CREB in Trh neurons (Sarkar et al. 2002) and mediates the effect of i.c.v. leptin injection, which rapidly increases pCREB in aPVN-TRH neurons (Perello et al. 2006). The adrenergic input may be relevant to thermogenesis because cold induces a fast increase in Trh mRNA levels in the aPVN as it does in the hypophysiotropic neurons (Sánchez et al. 2001). TRH neurons of the aPVN send projections to the ARC, dorsomedial, ventral-premammilary nuclei, and medialpreoptic region, and to several additional limbic regions such as various amygdaline nuclei, the bed nucleus of the stria terminalis, and lateral septum (Wittmann et al. 2009a). TRH neurons of the aPVN do not express GR (Cintra et al. 1990), but a corticosterone injection increases Trh mRNA levels, probably through direct stimulation of GC membrane receptors, and the cold-stimulatory effect is additive (Myers et al. 2014, Sotelo-Rivera et al. 2014). Trh expression in aPVN is not modulated after suckling or food restriction, whereas it is stimulated after dehydrationinduced anorexia (DIA; Sánchez et al. 2001, Alvarez-Salas et al. 2012). As regulation of biosynthesis is often coupled with changes in peptide release, the results indicate that aPVN-TRH neurons transfer multiple modalities of metabolically relevant information to postsynaptic targets; confirmation of their role will require experimental testing, but it is interesting to note that the intestinal administration of long-chain fatty acids enhances the activity of aPVN neurons (Randich et al. 2004), and adiponectin stimulates only non-neuroendocrine PVNTRH cells (Hoyda et al. 2009).

The ARC expresses both Trh-R1 and Trh-R2 receptor mRNAs (Heuer et al. 2000, Ebling et al. 2008), its dorsomedial part receives a dense TRHergic innervation (Lyons et al. 2010) arising, at least in part, from the aPVN and some from the perifornical area (Wittmann et al. 2009a,b). Cell-specific neuron-mapping techniques in mice demonstrate a strong excitatory drive emanating from subsets of neurons from the PVN expressing TRH and pituitaryadenylate cyclase-activating polypeptide that contact and activate AgRP neurons, inducing intense feeding (Krashes et al. 2014). The functional role of TRH in this circuit was not tested, but TRH does not regulate the electrical activity of $\alpha$-MSH or NPY neurons in slices of rat ARC (Zhang \& van den Pol 2012), instead TRH regulates that of tuberoinfundibular dopaminergic neurons present in the dorsal ARC which are surrounded by TRH-ir terminals; TRH causes a transition from phasic to tonic firing which probably decreases dopamine output (Lyons et al. 2010).

The DMH has an important role in energy homeostasis (Schneeberger et al. 2014). A significant population

Published by Bioscientifica Ltd 
of TRH neurons is detected in this nucleus (Hökfelt et al. 1989, Horjales-Araujo et al. 2014), which receive afferents from the subparaventricular zone, an output region from the suprachiasmatic nucleus ( $\mathrm{SCN})$; the DMH sends a glutamate-TRH projection to the LH area (Chou et al. 2003) which expresses both TRH receptors, predominantly TRH-R1 (Heuer et al. 2000). TRH receptors are probably present in orexin neurons as they respond to TRH with robust increases in their action potential firing rate, an effect that persists under conditions of synaptic isolation (González et al. 2009). TRH also increases the firing activity of presynaptic GABAergic interneurons (Hara et al. 2009). The DMH-TRHergic neuronal projection onto or near orexin neurons may be part of a circuit required for the circadian activation of behavioral and endocrine functions, including the circadian control of awareness (González et al. 2009). In agreement with this possibility, the effect of TRH on locomotor activity is reduced in orexin-ablated mice (Hara et al. 2009). TRH also inhibits the activity of melanin-concentrating hormone $(\mathrm{MCH})$ neurons of LH indirectly through the excitation of GABA neurons, a result consistent with the detection of TRH axons terminating on or near GABA neurons (Zhang \& van den Pol 2012). Interestingly, Trh mRNA levels in the DMH are increased after 2 weeks of moderate exercise compared with the pair-fed group (Uribe et al. 2014). The LH contains another large group of TRH cells throughout the rostrocaudal axis of the hypothalamus (Hökfelt et al. 1989, Lechan \& Segerson 1989, Heuer et al. 2000, Horjales-Araujo et al. 2014) and in the perifornical region (Wittmann et al. $2009 a, b)$. These neurons do not coexpress orexin, $\mathrm{MCH}$, or neurotensin (Horjales-Araujo et al. 2014). In the juxtaparaventricular area, a small group of TRH-immunoreactive cells stains for enkephalin and urocortin 3, and their projections partially overlap those of the aPVN (Wittmann et al. 2009b, Horjales-Araujo et al. 2014). AgRP and $\alpha$-MSH populations of terminals form close appositions onto TRH cells in the LH; the TRH-expressing cell population of the LH may link metabolic signals and the generation of arousal (Horjales-Araujo et al. 2014). Increased expression of Trh is detected in LH of male rats after 5 days of DIA and in the pair-fed group (de Gortari et al. 2009) while Crh mRNA levels increase only after DIA (Watts et al. 1999). DIA and pair-fed rats eat by the fifth day only $20 \%$ of the intake of control animals; the increase in TRH expression may be related to increased arousal as increased anxiety is produced by these conditions (Jaimes-Hoy et al. 2008).

TRH neurons heavily innervate histaminergic (HA) neurons in all subdivisions of the rat tuberomammillary nucleus (TMN) (Sárvári et al. 2012) where TRH-R2 is present (Gotoh et al. 2007). A TRH microinjection above the TMN activates HA TMN neurons and histamine turnover in PVN and VMH projections (Gotoh et al. 2007). As hypothalamic neuronal histamine is involved in the regulation of body weight and acts as an anorexic agent (Schneider et al. 2014), it is indeed possible that a HA projection contributes to the anorectic effect of TRH.

\section{Are changes in the expression of neuropeptides and TRH in total hypothalamus indicative of a metabolic alteration?}

Owing to the crucial involvement of $\mathrm{TH}$ thermogenesis and metabolism (Klieverik et al. 2009, Silva 2011, Mullur et al. 2014), a more active HPT would in principle reflect a higher metabolism. However, a cause-effect relationship between gene expression of ARC peptides and that of TRH in total PVN is difficult to identify (Table 1 and Supplementary Table 1). If, for example, there is an opposite response of $\mathrm{Trh}$ expression in aPVN versus mid-caudal PVN, the results of the whole PVN may overshadow the endocrine response. Even more if levels of expression are measured in total hypothalamus since TRH in several nuclei may have important roles in energy homeostasis. For example, comparison between lean and fat rats (Lou/C versus Wistar (Veyrat-Durebex et al. 2013)) or selectively bred chickens (Byerly et al. 2009) show increased Trh mRNA but also increased Npy and Agrp together with decreased Pomc in the lean animals which would seem to contradict the effects of these peptides on TRH expression in the PVN (Fekete \& Lechan 2014). Although it is not possible to delineate the hypothalamic regions where these reported changes occur, coincident changes in these two species include the enhanced expression of brain-derived neurotrophic factor (BDNF) which in vitro increases Trh mRNA levels (Ubieta et al. 2007). BDNF and its receptor TRKB are expressed in several hypothalamic nuclei including TRHergic cells of the PVN (Ubieta et al. 2007). BDNF regulates neurogenesis, neuronal plasticity, and support during development and throughout the animal's life-span (Jeanneteau \& Chao 2013). In the hypothalamus, BDNF plays an important part in energy homeostasis (Levin 2007, Rothman et al. 2012). Support for this role stems from the effects of transferring the Bdnf gene into hypothalami of adult mice, which display decreased body weight and body fat and increased expression of Mc4r, Lepr, Trh, and Crh compared with wild type mice despite having strangely greater than tenfold induction of the orexigenic peptides NPY and AgRP. Under HFD, they gained less weight and little fat

Published by Bioscientifica Ltd 
compared with normal mice and displayed increased Mc4r, Lepr, Trh, Crh, Cart (Cartpt), and Pomc expression, as well as expression of the metabolic genes of target tissues such as WAT and liver (Cao et al. 2009). These results, although not defining the particular hypothalamic nuclei involved, reveals the importance of additional participants such as BDNF in re-setting the response of several hypothalamic-peptidergic systems and their relationship with body weight and adipose tissue.

\section{Another metabolic relevant brain area, the hindbrain}

The brain stem is an important part of the circuitry involved in sensing and conveying information regarding the nutritional and energy conditions of the organism (Schneeberger et al. 2014). Trh is synthetized in the raphe pallidus (Rpa), raphe obscurus (Rob), and parapyramidal regions; these neurons project to neurons of the dorsal motor nucleus of the vagus, the nucleus tractus solitarius, and the ventrolateral medulla. They contain TRH-R1 and leptin receptors involved in coordinating vagal and sympathetic outflows (Taché et al. 2006). As in mid-PVN, Trh expression in these nuclei is downregulated in hyperthyroidism (Yuan \& Yang 1999) and upregulated by cold exposure (Taché et al. 2006). Some TRH neurons in the caudal raphe receive orexin afferents and project to premotor neurons that innervate BAT increasing thermogenesis; others project to the vagal circuit involved in hepatic, pancreatic, and gastrointestinal function (Taché et al. 2006). In contrast to the inhibitory effects of fasting on HPT activity, hindbrain Trh mRNA levels are elevated in rats fasted for 24 or $48 \mathrm{~h}$, and refeeding restores them to normal levels (Ao et al. 2006). Studies of the regulation of TRH expression in these neurons contribute to the understanding of the role of brain TRH in metabolism and thermogenesis.

\section{Neuroendocrinology revisited}

Recognition of the effects of environment on metabolism and epigenetic changes has led to questions with regard to what are the adequate controls in experimental research with rodents? Although laboratory rodents have been domesticated for hundreds of generations, their 'standard' living conditions are sedentary with no other activity but to eat ad libitum and develop obesity (Martin et al. 2010). This is evident comparing pair-fed with naïve rats; calorie restriction even as low as $18 \%$ of naïve food intake and loss of $8 \%$ body weight increased their corticosterone serum concentrations (Uribe et al. 2014). In the case of $300 \mathrm{~g}$ male rats, normal cages do not allow standing, reducing even further their possibility of physical activity (RSPCA 2011). Stressful conditions include differences in individual versus group housing depending on the age and sex of the animal, whether animals are transported or isolated within $1-3 \mathrm{~h}$ previous to the experiment, etc. (Koolhaas et al. 2011, Uribe et al. 2011).

Postnatal development, lactation, and adolescence are periods of high sensitivity to stress when epigenetic changes may program the individual to having low stress resilience, changing the expression of key molecules such as BDNF and GR in a region-specific manner; in hippocampus their inhibited expression alters the inhibitory feedback on the activity of the HPA leading to hyperactive stress responses and reduced learning (Meaney \& Szyf 2005, Pervanidou \& Chrousos 2012, Bath et al. 2013). The nutrition or stress experience of mothers during gestation as well as litter size has longlasting effects on metabolism and stress response (Breton 2013). In the case of the HPT axis and TRH expression in particular, reports are scarce. Dexamethasone injections during the last week of gestation diminish Trh mRNA levels in the PVN in female offspring and TRH fibers and $\mathrm{T}_{4}$ in both sexes during the second week; only Trh expression remained low in adult females, accompanied by low body temperature during estrous and diestrous (Carbone et al. 2012a). Low levels of immunoreactive TRH are also detected in the fibers of the LH (Carbone et al. 2012b). This treatment blunts stress-induced $B d n f$ expression in male rats or HFD-induced increases in females (Carbone $\&$ Handa 2013).

Neonatal stress produced by maternal separation causes epigenetic changes in hippocampal $G r$ and $B d n f$ promoters, their reduced expression contributes to the altered HPA-response to stressors in adulthood (Meaney $\&$ Szyf 2005), Bdnf expression is altered in a strain-, sex-, and region-specific manner (Bath et al. 2013). Adequate programing of activity and response of the HPT axis is altered under various conditions. Maternal separation increases $p p T r h$ mRNA in the aPVN and circulating $\mathrm{T}_{4}$ serum concentrations of adult rats, and attenuates the response to exercise or cold exposure but that to fasting is normal (Jaimes-Hoy et al. 2013). Offspring of mothers that experienced a $40 \%$ food restriction, during gestation and lactation were hypothyroid (low $\mathrm{FT}_{4}$ and high $\mathrm{TSH}$ ) and had a blunted response to $24 \mathrm{~h}$ cold exposure (AyalaMoreno et al. 2013). In contrast, post-natal overnutrition during lactation, which predisposes the offspring to being overweight, leads to leptin resistance and overexpression

Published by Bioscientifica Ltd 
of orexigenic pathways (Breton 2013), alters the HPT axis in rats in contrast to the situation opposite to what is observed after HFD because Trh expression in the PVN and $\mathrm{T}_{4}$ serum concentration are decreased and the response to fasting is suppressed (Rodrigues et al. 2009, AréchigaCeballos et al. 2014) compared with HFD-induced overweight, which display increased Trh mRNA and TH serum levels, but without an altered fasting response (Perello et al. 2010).

The opposite scenarios apply to mice grown in enriched environments; their body weight is reduced, $\mathrm{BDNF}$ expression is increased in ARC and $\mathrm{DMH} / \mathrm{VMH}$, Trh in the PVN and in the DMH/VMH, despite decreased expression of Pomc; animals with access to wheels for running for several weeks maintain lower body weight and reduced adiposity, but Trh mRNA levels tend to decrease and $\mathrm{Crh}$ and $\mathrm{Crh}$-receptors increase in contrast to the effects of the enriched environment (Cao et al. 2011). The contradictory results observed between the effects of neonatal stress and those of growing in an enriched environment on the relationship of GR and BDNF (Jeanneteau \& Chao 2013) include the responses of the HPA, HPT, and SNA that affect energy balance. Improvements and standardized housing conditions seem required to define adequate controls and obtain reproducible data between different laboratories, together with adequate reports of the animals' age and body weight, as some correspond to the adolescent period (McCutcheon \& Marinelli 2009). Another recently discovered but very important problem is the materials used in animal houses such as water bottles made of polycarbonate that release chemicals that act as endocrine disruptors causing deleterious effects, particularly during development (Zoeller 2010), and the differential leakage that occurs depending on the state and treatment of the bottle (Guart et al. 2013).

\section{Conclusion}

This review summarizes what is known about the regulation of the TRHergic neurons involved in energy homeostasis and the interfering effects of stress. In spite of the limitations of the in vitro systems or transgenic mice models, evidence indicates demonstrate an inhibitory role of $\mathrm{T}_{3}$ and a stimulatory one of pCREB, SP1/KPL, GR-cJun, and STAT3 on Trh transcription; interaction of the transduction pathways involved may explain some of the interfering effects of stress on neuronal stimulations observed in various in vivo situations, but they have not yet been fully placed in a sub-type of TRH neuron context.
Trh expression levels in the PVN, detected during chronic 'static' situations, are difficult to relate to changes in other known modulators as they represent a 'snap shot' that might not readily correspond to the activity of the target organs involved. TRH neurons can rapidly respond to energy demands for thermogenesis or physical activity; these responses may be modified due to nutritional status, and stress history. We propose that combined approaches of chronic situations with acute responses might lead to a better understanding of TRH physiology in the PVN and in other relevant metabolic hypothalamic nuclei.

\section{Supplementary data}

This is linked to the online version of the paper at http://dx.doi.org/10.1530/ JOE-14-0593.

\section{Declaration of interest}

The authors declare that there is no conflict of interest that could be perceived as prejudicing the impartiality of the review.

\section{Funding}

Drs $\mathrm{P} J-\mathrm{B}$ and $\mathrm{J}-\mathrm{L} \mathrm{C}$ have received constant support from the Universidad Nacional Autónoma de México (UNAM), the Dirección General Asuntos del Personal Académico-UNAM (DGAPA-UNAM) and the National Science Agency, Consejo Nacional de Ciencia y Tecnología (CONACYT). Recent funding: CONACYT 180009, 154931; DGAPA IN204913, IN206712.

\section{Acknowledgements}

The authors thank the academic staff and students whose work is cited here. The constant help of the administrative personnel and technicians of the Institute, in particular for this review to our librarian S. Ainsworth, is greatly acknowledged. They apologise to those authors whose work was not included in the reference list but, due to space constraints, it is cited only in the reviews.

\section{References}

Abel ED, Ahima RS, Boers ME, Elmquist JK \& Wondisford FE 2001 Critical role for thyroid hormone receptor $\beta 2$ in the regulation of paraventricular thyrotropin-releasing hormone neurons. Journal of Clinical Investigation 107 1017-1023. (doi:10.1172/JCI10858)

Aguilar-Valles A, Sánchez E, de Gortari P, Ramírez-Amaya V, Balderas I, Bermúdez-Ratoni F \& Joseph-Bravo P 2005 Analysis of the stress response in rats trained in the water-maze: differential expression of CRH, CRH-R1, GR and BDNF in limbic regions. Neuroendocrinology $\mathbf{8 2}$ 306-319. (doi:10.1159/000093129)

Aguilar-Valles A, Sánchez E, de Gortari P, García-Vázquez I, Ramírez-Amaya V, Bermúdez-Ratoni F \& Joseph-Bravo P 2007 The expression of TRH, its receptors and degrading enzyme is differentially modulated in the rat limbic system during training in the Morris Water Maze. Neurochemistry International 50 404-417. (doi:10.1016/j.neuint.2006. 09.009)

Published by Bioscientifica Ltd. 
Akieda-Asai S, Poleni PE \& Date Y 2014 Coinjection of CCK and leptin reduces food intake via increased CART/TRH and reduced AMPK phosphorylation in the hypothalamus. American Journal of Physiology. Endocrinology and Metabolism 306 E1284-E1291. (doi:10.1152/ajpendo. 00664.2013)

Alkemade A, Unmehopa UA, Wiersinga WM, Swaab DF \& Fliers E 2005 Glucocorticoids decrease thyrotropin-releasing hormone messenger ribonucleic acid expression in the paraventricular nucleus of the human hypothalamus. Journal of Clinical Endocrinology and Metabolism 90 323-327. (doi:10.1210/jc.2004-1430)

Altarejos JY \& Montminy M 2011 CREB and the CRTC co-activators: sensors for hormonal and metabolic signals. Nature Reviews. Molecular Cell Biology 12 141-151. (doi:10.1038/nrm3072)

Alvarez-Salas E, Aceves C, Anguiano B, Uribe RM, García-Luna C, Sánchez E \& de Gortari P 2012 Food-restricted and dehydrated-induced anorexic rats present differential TRH expression in anterior and caudal PVN. Role of type 2 deiodinase and pyroglutamyl aminopeptidase II. Endocrinology 153 4067-4076. (doi:10.1210/en.2011-2011)

Ao Y, Go VL, Toy N, Li T, Wang Y, Song MK, Reeve JR Jr, Liu Y \& Yang H 2006 Brainstem thyrotropin-releasing hormone regulates food intake through vagal-dependent cholinergic stimulation of ghrelin secretion. Endocrinology 147 6004-6010. (doi:10.1210/en.2006-0820)

Araujo RL, Andrade BM, da Silva ML, Ferreira AC \& Carvalho DP 2009 Tissue-specific deiodinase regulation during food restriction and low replacement dose of leptin in rats. American Journal of Physiology. Endocrinology and Metabolism 296 E1157-E1163. (doi:10.1152/ajpendo. 90869.2008)

Aréchiga-Ceballos F, Alvarez-Salas E, Matamoros-Trejo G, Amaya MI, García-Luna C \& de Gortari P 2014 Pro-TRH and pro-CRF expression in paraventricular nucleus of small litter-reared fasted adult rats. Journal of Endocrinology 221 77-88. (doi:10.1530/JOE-13-0458)

Armario A \& Castellanos JM 1984 Effect of acute and chronic psychogenic stress on corticoadrenal and pituitary-thyroid hormones in male rats. Hormone Research 20 241-245. (doi:10.1159/000180003)

Astapova I \& Hollenberg AN 2013 The in vivo role of nuclear receptor corepressors in thyroid hormone action. Biochimica et Biophysica Acta 1830 3876-3881. (doi:10.1016/j.bbagen.2012.07.001)

Ayala-Moreno R, Racotta R, Anguiano B, Aceves C \& Quevedo L 2013 Perinatal undernutrition programmes thyroid function in the adult rat offspring. British Journal of Nutrition 110 2207-2215. (doi:10.1017/ S0007114513001736)

Bath KG, Schilit A \& Lee FS 2013 Stress effects on BDNF expression: effects of age, sex, and form of stress. Neuroscience 239 149-156. (doi:10.1016/ j.neuroscience.2013.01.074)

Boler J, Enzmann F, Folkers K, Bowers CY \& Schally AV 1969 The identity of chemical and hormonal properties of the thyrotropin releasing hormone and pyroglutamyl-histidyl-proline amide. Biochemical and Biophysical Research Communications 37 705-710. (doi:10.1016/0006291X(69)90868-7)

Breton C 2013 The hypothalamus-adipose axis is a key target of developmental programming by maternal nutritional manipulation. Journal of Endocrinology 216 R19-R31. (doi:10.1530/JOE-12-0157)

Brown LM \& Clegg DJ 2010 Central effects of estradiol in the regulation of food intake, body weight, and adiposity. Journal of Steroid Biochemistry and Molecular Biology 122 65-73. (doi:10.1016/j.jsbmb.2009.12.005)

Burgus R, Dunn TF, Desiderio D \& Guillemin R 1969 Molecular structure of the hypothalamic hypophysiotropic TRF factor of ovine origin: mass spectrometry demonstration of the PCA-His-Pro- $\mathrm{NH}_{2}$ sequence. Comptes Rendus Hebdomadaires des Séances de l'Acadmie des Sciences. Série D: Sciences Naturelles 269 1870-1873.

Byerly MS, Simon J, Lebihan-Duval E, Duclos MJ, Cogburn LA \& Porter TE 2009 Effects of BDNF, $\mathrm{T}_{3}$, and corticosterone on expression of the hypothalamic obesity gene network in vivo and in vitro. American Journal of Physiology. Regulatory, Integrative and Comparative Physiology 296 R1180-R1189. (doi:10.1152/ajpregu.90813.2008)
Cao L, Lin EJ, Cahill MC, Wang C, Liu X \& During MJ 2009 Molecular therapy of obesity and diabetes by a physiological autoregulatory approach. Nature Medicine 15 447-454. (doi:10.1038/nm.1933)

Cao L, Choi EY, Liu X, Martin A, Wang C, Xu X \& During MJ 2011 White to brown fat phenotypic switch induced by genetic and environmental activation of a hypothalamic-adipocyte axis. Cell Metabolism 14 324-338. (doi:10.1016/j.cmet.2011.06.020)

Carbone DL \& Handa RJ 2013 Sex and stress hormone influences on the expression and activity of brain-derived neurotrophic factor. Neuroscience 239 295-303. (doi:10.1016/j.neuroscience.2012.10.073)

Carbone DL, Zuloaga DG, Lacagnina AF, McGivern RF \& Handa RJ $2012 a$ Exposure to dexamethasone during late gestation causes femalespecific decreases in core body temperature and prepro-thyrotropinreleasing hormone expression in the paraventricular nucleus of the hypothalamus in rats. Physiology \& Behavior 108 6-12. (doi:10.1016/j. physbeh.2012.07.010)

Carbone DL, Zuloaga DG, Lacagnina AF \& Handa RJ 2012b Preprothyrotropin releasing hormone expressing neurons in the juxtaparaventricular region of the lateral hypothalamus are activated by leptin and altered by prenatal glucocorticoid exposure. Brain Research 1477 19-26. (doi:10.1016/j.brainres.2012.08.020)

Case HS, Reed HL, Palinkas LA, Reedy KR, Van Do N, Finney NS \& Seip R 2006 Resting and exercise energy use in Antarctica: effect of 50\% restriction in temperate climate energy requirements. Clinical Endocrinology 65 257-264. (doi:10.1111/j.1365-2265.2006.02588.x)

Charli JL, Vargas MA, Cisneros M, de Gortari P, Baeza MA, Jasso P, Bourdais J, Pérez L, Uribe RM \& Joseph-Bravo P 1998 TRH inactivation in the extracellular compartment: role of pyroglutamyl peptidase II. Neurobiology 6 45-57.

Charmandari E, Tsigos C \& Chrousos G 2005 Endocrinology of the stress response. Annual Review of Physiology 67 259-284. (doi:10.1146/ annurev.physiol.67.040403.120816)

Chiamolera MI \& Wondisford FE 2009 Minireview: Thyrotropin-releasing hormone and the thyroid hormone feedback mechanism. Endocrinology 150 1091-1096. (doi:10.1210/en.2008-1795)

Chiamolera MI, Sidhaye AR, Matsumoto S, He Q, Hashimoto K, OrtigaCarvalho TM \& Wondisford FE 2012 Fundamentally distinct roles of thyroid hormone receptor isoforms in a thyrotroph cell line are due to differential DNA binding. Molecular Endocrinology 26 926-939. (doi:10.1210/me.2011-1290)

Chiappini F, Ramadoss P, Vella KR, Cunha LL, Ye FD, Stuart RC, Nillni EA \& Hollenberg AN 2013 Family members CREB and CREM control thyrotropin-releasing hormone (TRH) expression in the hypothalamus. Molecular and Cellular Endocrinology 365 84-94. (doi:10.1016/j.mce. 2012.09.006)

Chou TC, Scammell TE, Gooley JJ, Gaus SE, Saper CB \& Lu J 2003 Critical role of dorsomedial hypothalamic nucleus in a wide range of behavioral circadian rhythms. Journal of Neuroscience 23 10691-10702.

Cintra A, Fuxe K, Wikström AC, Visser T \& Gustafsson JA 1990 Evidence for thyrotropin-releasing hormone and glucocorticoid receptor-immunoreactive neurons in various preoptic and hypothalamic nuclei of the male rat. Brain Research 506 139-144. (doi:10.1016/0006-8993(90)91210-8)

Cizza G, Brady LS, Esclapes ME, Blackman MR, Gold PW \& Chrousos GP 1996 Age and gender influence basal and stress-modulated hypothalamic-pituitary-thyroidal function in Fischer 344/N rats. Neuroendocrinology 64 440-448. (doi:10.1159/000127150)

Cote-Vélez A, Pérez-Martínez L, Díaz-Gallardo MY, Pérez-Monter C, Carreón-Rodríguez A, Charli JL \& Joseph-Bravo P 2005 Dexamethasone represses cAMP rapid upregulation of TRH gene transcription: identification of a composite glucocorticoid response element and a cAMP response element in TRH promoter. Journal of Molecular Endocrinology 34 177-197. (doi:10.1677/jme.1.01634)

Cote-Vélez A, Pérez-Martínez L, Charli JL \& Joseph-Bravo P 2008 The PKC and ERK/MAPK pathways regulate glucocorticoid action on TRH transcription. Neurochemical Research 33 1582-1591. (doi:10.1007/ s11064-008-9698-5) 
Cote-Vélez A, Pérez-Maldonado A, Osuna J, Barrera B, Charli JL \& Joseph-Bravo P 2011 Creb and Sp/Krüppel response elements cooperate to control rat TRH gene transcription in response to cAMP. Biochimica et Biophysica Acta 1809 191-199. (doi:10.1016/j.bbagrm.2011.01.005)

Dallman MF, Akana SF, Pecoraro NC, Warne JP, la Fleur SE \& Foster MT 2007 Glucocorticoids, the etiology of obesity and the metabolic syndrome. Current Alzheimer Research 4 199-204. (doi:10.2174/ 156720507780362236)

Decherf S, Seugnet I, Becker N, Demeneix BA \& Clerget-Froidevaux MS 2013 Retinoic X receptor subtypes exert differential effects on the regulation of Trh transcription. Molecular and Cellular Endocrinology $\mathbf{3 8 1}$ 115-123. (doi:10.1016/j.mce.2013.07.016)

Di S, Malcher-Lopes R, Halmos KC \& Tasker JG 2003 Nongenomic glucocorticoid inhibition via endocannabinoid release in the hypothalamus: a fast feedback mechanism. Journal of Neuroscience $\mathbf{2 3}$ 4850-4857.

Díaz-Gallardo MY, Cote-Vélez A, Carreón-Rodríguez A, Charli JL \& Joseph-Bravo P 2010a Phosphorylated cyclic-AMP-response elementbinding protein and thyroid hormone receptor have independent response elements in the rat thyrotropin-releasing hormone promoter: an analysis in hypothalamic cells. Neuroendocrinology 91 64-76. (doi:10.1159/000228833)

Díaz-Gallardo MY, Cote-Vélez A, Charli JL \& Joseph-Bravo P $2010 b$ A rapid interference between glucocorticoids and cAMP-activated signalling in hypothalamic neurones prevents binding of phosphorylated cAMP response element binding protein and glucocorticoid receptor at the CRE-like and composite GRE sites of thyrotrophin-releasing hormone gene promoter. Journal of Neuroendocrinology 22 282-293. (doi:10.1111/ j.1365-2826.2010.01966.x)

Duclos M, Timofeeva E, Michel C \& Richard D 2005 Corticosteronedependent metabolic and neuroendocrine abnormalities in obese Zucker rats in relation to feeding. American Journal of Physiology. Endocrinology and Metabolism 288 E254-E266. (doi:10.1152/ajpendo. 00087.2004)

Dupré SM, Guissouma H, Flamant F, Seugnet I, Scanlan TS, Baxter JD, Samarut J, Demeneix BA \& Becker N 2004 Both thyroid hormone receptor (TR) $\beta 1$ and TR $\beta 2$ isoforms contribute to the regulation of hypothalamic thyrotropin-releasing hormone. Endocrinology 145 2337-2345. (doi:10.1210/en.2003-1209)

Ebling FJ, Wilson D, Wood J, Hughes D, Mercer JG, Morgan PJ \& Barrett P 2008 The thyrotropin-releasing hormone secretory system in the hypothalamus of the Siberian hamster in long and short photoperiods. Journal of Neuroendocrinology 20 576-586. (doi:10.1111/j.1365-2826. 2008.01702.x)

Fekete C \& Lechan RM 2014 Central regulation of hypothalamic-pituitarythyroid axis under physiological and pathophysiological conditions. Endocrine Reviews 35 159-194. (doi:10.1210/er.2013-1087)

Fliers E, Unmehopa UA \& Alkemade A 2006 Functional neuroanatomy of thyroid hormone feedback in the human hypothalamus and pituitary gland. Molecular and Cellular Endocrinology 251 1-8. (doi:10.1016/j.mce. 2006.03.042)

Fliers E, Kalsbeek A \& Boelen A 2014 Mechanisms in endocrinology: Beyond the fixed set point of the hypothalamus-pituitary-thyroid axis. European Journal of Endocrinology 171 R197-R208. (doi:10.1530/EJE-14-0285)

Füzesi T, Wittmann G, Lechan RM, Liposits Z \& Fekete C 2009 Noradrenergic innervation of hypophysiotropic thyrotropin-releasing hormone-synthesizing neurons in rats. Brain Research 1294 38-44. (doi:10.1016/j.brainres.2009.07.094)

Gadaleta RM \& Magnani L 2014 Nuclear receptors and chromatin: an inducible couple. Journal of Molecular Endocrinology 52 R137-R149. (doi:10.1530/JME-13-0170)

Galas L, Raoult E, Tonon MC, Okada R, Jenks BG, Castaño JP, Kikuyama S, Malagon M, Roubos EW \& Vaudry H 2009 TRH acts as a multifunctional hypophysiotropic factor in vertebrates. General and Comparative Endocrinology 164 40-50. (doi:10.1016/j.ygcen.2009.05.003)
Ghamari-Langroudi M, Vella KR, Srisai D, Sugrue ML, Hollenberg AN \& Cone RD 2010 Regulation of thyrotropin-releasing hormoneexpressing neurons in paraventricular nucleus of the hypothalamus by signals of adiposity. Molecular Endocrinology 24 2366-2381. (doi:10.1210/me.2010-0203)

González JA, Horjales-Araujo E, Fugger L, Broberger C \& Burdakov D 2009 Stimulation of orexin/hypocretin neurones by thyrotropin-releasing hormone. Journal of Physiology 587 1179-1186. (doi:10.1113/jphysiol. 2008.167940)

de Gortari P, Mancera K, Martínez A, Cote-Vélez A \& Joseph-Bravo P 2009 Involvement of CRH-R2 in eating behavior and in the response of the HPT axis in rats subjected to dehydration-induced anorexia. Psychoneuroendocrinology 34 259-272. (doi:10.1016/j.psyneuen.2008.09.010)

Gotoh K, Fukagawa K, Fukagawa T, Noguchi H, Kakuma T, Sakata T \& Yoshimatsu H 2007 Hypothalamic neuronal histamine mediates the thyrotropin-releasing hormone-induced suppression of food intake. Journal of Neurochemistry 103 1102-1110. (doi:10.1111/j.1471-4159. 2007.04802.x)

Guart A, Wagner M, Mezquida A, Lacorte S, Oehlmann J \& Borrell A 2013 Migration of plasticisers from Tritan ${ }^{\mathrm{TM}}$ and polycarbonate bottles and toxicological evaluation. Food Chemistry 141 373-380. (doi:10.1016/j. foodchem.2013.02.129)

Guissouma H, Becker N, Seugnet I \& Demeneix BA 2000 Transcriptional repression of TRH promoter function by $\mathrm{T}_{3}$ : analysis by in vivo gene transfer. Biochemistry and Cell Biology 78 155-163. (doi:10.1139/o00-009)

Guo F, Bakal K, Minokoshi Y \& Hollenberg AN 2004 Leptin signaling targets the thyrotropin-releasing hormone gene promoter in vivo. Endocrinology 145 2221-2227. (doi:10.1210/en.2003-1312)

Gutiérrez-Mariscal M, de Gortari P, López-Ruvalcaba C, Martínez A \& Joseph-Bravo P 2008 Analysis of the anxiolytic-like effect of TRH and the response of amygdalar TRHergic neurons in anxiety. Psychoneuroendocrinology 33 198-213. (doi:10.1016/j.psyneuen.2007. 11.002)

Gutiérrez-Mariscal M, Sánchez E, García-Vázquez A, Rebolledo-Solleiro D, Charli JL \& Joseph-Bravo P 2012 Acute response of hypophysiotropic thyrotropin releasing hormone neurons and thyrotropin release to behavioral paradigms producing varying intensities of stress and physical activity. Regulatory Peptides 179 61-70. (doi:10.1016/j.regpep. 2012.08.010)

van Haasteren GA, Linkels E, Klootwijk W, van Toor H, Rondeel JM, Themmen AP, de Jong FH, Valentijn K, Vaudry H, Bauer K et al. 1995 Starvation-induced changes in the hypothalamic content of prothyrotrophin-releasing hormone (proTRH) mRNA and the hypothalamic release of proTRH-derived peptides: role of the adrenal gland. Journal of Endocrinology 145 143-153. (doi:10.1677/joe.0.1450143)

van Haasteren GA, Linkels E, van Toor H, Klootwijk W, Kaptein E, de Jong FH, Reymond MJ, Visser TJ \& de Greef WJ 1996 Effects of long-term food reduction on the hypothalamus-pituitary-thyroid axis in male and female rats. Journal of Endocrinology 150 169-178. (doi:10.1677/joe. 0.1500169 )

Hara J, Gerashchenko D, Wisor JP, Sakurai T, Xie X \& Kilduff TS 2009 Thyrotropin-releasing hormone increases behavioral arousal through modulation of hypocretin/orexin neurons. Journal of Neuroscience 29 3705-3714. (doi:10.1523/JNEUROSCI.0431-09.2009)

Harris M, Aschkenasi C, Elias CF, Chandrankunnel A, Nillni EA, Bjøorbaek C, Elmquist JK, Flier JS \& Hollenberg AN 2001 Transcriptional regulation of the thyrotropin-releasing hormone gene by leptin and melanocortin signaling. Journal of Clinical Investigation 107 111-120. (doi:10.1172/ JCI10741)

Helmreich DL, Parfitt DB, Lu XY, Akil H \& Watson SJ 2005 Relation between the hypothalamic-pituitary-thyroid (HPT) axis and the hypothalamic-pituitary-adrenal (HPA) axis during repeated stress. Neuroendocrinology 81 183-192. (doi:10.1159/000087001)

Heuer H, Schäfer MK, O'Donnell D, Walker P \& Bauer K 2000 Expression of thyrotropin-releasing hormone receptor 2 (TRH-R2) in the central nervous system of rats. Journal of Comparative Neurology 428 319-336.

Published by Bioscientifica Ltd. 
(doi:10.1002/1096-9861(20001211)428:2<319::AID-CNE10>3.0. CO;2-9)

Hinkle PM, Gehret AU \& Jones BW 2012 Desensitization, trafficking, and resensitization of the pituitary thyrotropin-releasing hormone receptor. Frontiers in Neuroscience 13 180. (doi:10.3389/fnins.2012. 00180)

Hökfelt T, Tsuruo Y, Ulfhake B, Cullheim S, Arvidsson U, Foster GA, Schultzberg M, Schalling M, Arborelius L, Freedman J et al. 1989 Distribution of TRH-like immunoreactivity with special reference to coexistence with other neuroactive compounds. Annals of the New York Academy of Sciences 553 76-105. (doi:10.1111/j.1749-6632.1989. tb54479.x)

Hollenberg AN 2008 The role of the thyrotropin-releasing hormone (TRH) neuron as a metabolic sensor. Thyroid 18 131-139. (doi:10.1089/thy. 2007.0251)

Horjales-Araujo E, Hellysaz A \& Broberger C 2014 Lateral hypothalamic thyrotropin-releasing hormone neurons: distribution and relationship to histochemically defined cell populations in the rat. Neuroscience $\mathbf{2 7 7}$ 87-102. (doi:10.1016/j.neuroscience.2014.06.043)

Hoyda TD, Samson WK \& Ferguson AV 2009 Adiponectin depolarizes parvocellular paraventricular nucleus neurons controlling neuroendocrine and autonomic function. Endocrinology 150 832-840. (doi:10.1210/en.2008-1179)

Huo L, Münzberg H, Nillni EA \& Bjørbaek C 2004 Role of signal transducer and activator of transcription 3 in regulation of hypothalamic trh gene expression by leptin. Endocrinology 145 2516-2523. (doi:10.1210/en. 2003-1242)

Jaimes-Hoy L, Joseph-Bravo P \& de Gortari P 2008 Differential response of TRHergic neurons of the PVN in animals submitted to food restriction or dehydration induced anorexia and cold exposure. Hormones and Behavior 53 366-377. (doi:10.1016/j.yhbeh.2007.11.003)

Jaimes-Hoy L, Espinosa-Ayala C, Charli JL \& Joseph-Bravo PI 2013 Maternal separation persistently alters the expression of key elements of the neuroendocrine TRH system. Endo 2013, The Endocrine Society's 95th Annual Meeting \& Expo, San Francisco, CA, USA. Abstract MON-428.

Jeanneteau F \& Chao MV 2013 Are BDNF and glucocorticoid activities calibrated? Neuroscience 239 173-195. (doi:10.1016/j.neuroscience. 2012.09.017)

John CD, Christian HC, Morris JF, Flower RJ, Solito E \& Buckingham JC 2003 Kinase-dependent regulation of the secretion of thyrotrophin and luteinizing hormone by glucocorticoids and annexin 1 peptides. Journal of Neuroendocrinology 15 946-957. (doi:10.1046/j.1365-2826.2003.01081.x)

Kádár A, Sánchez E, Wittmann G, Singru PS, Füzesi T, Marsili A, Larsen PR, Liposits Z, Lechan RM \& Fekete C 2010 Distribution of hypophysiotropic thyrotropin-releasing hormone (TRH)-synthesizing neurons in the hypothalamic paraventricular nucleus of the mouse. Journal of Comparative Neurology 518 3948-3961. (doi:10.1002/cne.22432)

Kakucska I, Qi Y \& Lechan RM 1995 Changes in adrenal status affect hypothalamic thyrotropin-releasing hormone gene expression in parallel with corticotropin-releasing hormone. Endocrinology 136 2795-2802. (doi:10.1210/endo.136.7.7789304)

Kalsbeek A, Fliers E, Franke AN, Wortel J \& Buijs RM 2000 Functional connections between the suprachiasmatic nucleus and the thyroid gland as revealed by lesioning and viral tracing techniques in the rat. Endocrinology 141 3832-3841.

Kilburn-Watt E, Banati RB \& Keay KA 2010 Altered thyroid hormones and behavioural change in a sub-population of rats following chronic constriction injury. Journal of Neuroendocrinology 22 960-970. (doi:10.1111/j.1365-2826.2010.02038.x)

Klieverik LP, Coomans CP, Endert E, Sauerwein HP, Havekes LM, Voshol PJ, Rensen PC, Romijn JA, Kalsbeek A \& Fliers E 2009 Thyroid hormone effects on whole-body energy homeostasis and tissue-specific fatty acid uptake in vivo. Endocrinology 150 5639-5648. (doi:10.1210/en.2009-0297)

de Kloet ER 2014 From receptor balance to rational glucocorticoid therapy. Endocrinology 155 2754-2769. (doi:10.1210/en.2014-1048)
Koolhaas JM, Bartolomucci A, Buwalda B, de Boer SF, Flügge G, Korte SM, Meerlo P, Murison R, Olivier B, Palanza P et al. 2011 Stress revisited: a critical evaluation of the stress concept. Neuroscience and Biobehavioral Reviews 35 1291-1301. (doi:10.1016/j.neubiorev.2011.02.003)

Krashes MJ, Shah BP, Madara JC, Olson DP, Strochlic DE, Garfield AS, Vong L, Pei H, Watabe-Uchida M, Uchida N et al. 2014 An excitatory paraventricular nucleus to AgRP neuron circuit that drives hunger. Nature 507 238-242. (doi:10.1038/nature12956)

Lechan RM \& Fekete C 2006 The TRH neuron: a hypothalamic integrator of energy metabolism. Progress in Brain Research 153 209-235. (doi:10.1016/S0079-6123(06)53012-2)

Lechan RM \& Segerson TP 1989 Pro-TRH gene expression and precursor peptides in rat brain. Observations by hybridization analysis and immunocytochemistry. Annals of the New York Academy of Sciences $\mathbf{5 5 3}$ 29-59. (doi:10.1111/j.1749-6632.1989.tb54476.x)

Lechan RM, Wu P, Jackson IM, Wolf H, Cooperman S, Mandel G \& Goodman RH 1986 Thyrotropin-releasing hormone precursor: characterization in rat brain. Science 231 159-161. (doi:10.1126/ science.3079917)

Lee SL, Stewart K \& Goodman RH 1988 Structure of the gene encoding rat thyrotropin releasing hormone. Journal of Biological Chemistry 263 16604-16609.

Levin BE 2007 Neurotrophism and energy homeostasis: perfect together American Journal of Physiology. Regulatory, Integrative and Comparative Physiology 293 R988-R991. (doi:10.1152/ajpregu.00434.2007)

Lima LP, Barros IA, Lisbôa PC, Araújo RL, Silva AC, Rosenthal D, Ferreira AC \& Carvalho DP 2006 Estrogen effects on thyroid iodide uptake and thyroperoxidase activity in normal and ovariectomized rats. Steroids $\mathbf{7 1}$ 653-659. (doi:10.1016/j.steroids.2006.03.007)

Louzada RA, Santos MC, Cavalcanti-de-Albuquerque JP, Rangel I, Ferreira AC, Galina A, Werneck de Castro JP \& de Carvalho DP 2014 Type 2 iodothyronine deiodinase is up-regulated in rat slow- and fast-twitch skeletal muscle during cold exposure. American Journal of Physiology. Endocrinology and Metabolism 307 E1020-E1029. (doi:10.1152/ajpendo. 00637.2013)

Lundblad JR, Kwok RP, Laurance ME, Huang MS, Richards JP, Brennan RG \& Goodman RH 1998 The human T-cell leukemia virus-1 transcriptional activator Tax enhances cAMP-responsive element-binding protein (CREB) binding activity through interactions with the DNA minor groove. Journal of Biological Chemistry 273 19251-19259. (doi:10.1074/jbc.273.30.19251)

Lyons DJ, Horjales-Araujo E \& Broberger C 2010 Synchronized network oscillations in rat tuberoinfundibular dopamine neurons: switch to tonic discharge by thyrotropin-releasing hormone. Neuron 65 217-229. (doi:10.1016/j.neuron.2009.12.024)

Maniam J \& Morris MJ 2012 The link between stress and feeding behaviour. Neuropharmacology 63 97-110. (doi:10.1016/j.neuropharm.2012.04.017)

Marassi MP, Fortunato RS, da Silva AC, Pereira VS, Carvalho DP, Rosenthal D $\&$ da Costa VM 2007 Sexual dimorphism in thyroid function and type 1 iodothyronine deiodinase activity in pre-pubertal and adult rats. Journal of Endocrinology 192 121-130. (doi:10.1677/joe.1.06901)

Markakis EA \& Swanson LW 1997 Spatiotemporal patterns of secretomotor neuron generation in the parvicellular neuroendocrine system. Brain Research. Brain Research Reviews 24 255-291. (doi:10.1016/S01650173(97)00006-4)

Martin B, Ji S, Maudsley S \& Mattson MP 2010 “Control” laboratory rodents are metabolically morbid: why it matters. PNAS 107 6127-6133. (doi:10.1073/pnas.0912955107)

Mastorakos G \& Pavlatou M 2005 Exercise as a stress model and the interplay between the hypothalamus-pituitary-adrenal and the hypothalamus-pituitary-thyroid axes. Hormone and Metabolic Research 37 577-584. (doi:10.1055/s-2005-870426)

McAninch EA \& Bianco AC 2014 Thyroid hormone signaling in energy homeostasis and energy metabolism. Annals of the New York Academy of Sciences 1311 77-87. (doi:10.1111/nyas.12374) 
McCutcheon JE \& Marinelli M 2009 Age matters. European Journal of Neuroscience 29 997-1014. (doi:10.1111/j.1460-9568.2009.06648.x)

Meaney MJ \& Szyf M 2005 Environmental programming of stress responses through DNA methylation: life at the interface between a dynamic environment and a fixed genome. Dialogues in Clinical Neuroscience 7 103-123.

Mitchell SE, Nogueiras R, Rance K, Rayner DV, Wood S, Dieguez C \& Williams LM 2006 Circulating hormones and hypothalamic energy balance: regulatory gene expression in the Lou/C and Wistar rats. Journal of Endocrinology 190 571-579. (doi:10.1677/joe.1.06576)

Mullur R, Liu YY \& Brent GA 2014 Thyroid hormone regulation of metabolism. Physiological Reviews 94 355-382. (doi:10.1152/physrev. 00030.2013)

Myers B, McKlveen JM \& Herman JP 2014 Glucocorticoid actions on synapses, circuits, and behavior: implications for the energetics of stress. Frontiers in Neuroendocrinology 35 180-196. (doi:10.1016/j.yfrne. 2013.12.003)

Nillni EA 2010 Regulation of the hypothalamic thyrotropin releasing hormone (TRH) neuron by neuronal and peripheral inputs. Frontiers in Neuroendocrinology 3 134-156. (doi:10.1016/j.yfrne.2010.01.001)

Osterlund C \& Spencer R 2011 Corticosterone pretreatment suppresses stress-induced hypothalamic-pituitary-adrenal axis activity via multiple actions that vary with time, site of action, and de novo protein synthesis. Journal of Endocrinology 208 311-322. (doi:10.1530/ JOE-10-0413)

Palinkas LA, Reedy KR, Shepanek M, Smith M, Anghel M, Steel GD, Reeves D, Case HS, Do NV \& Reed HL 2007 Environmental influences on hypothalamic-pituitary-thyroid function and behavior in Antarctica. Physiology \& Behavior 92 790-799. (doi:10.1016/j.physbeh.2007.06.008)

Paxinos G \& Watson C 2005 In The Rat Brain in Stereoaxic Coordinates, 5 th ed. San Diego, CA, USA: Elsevier.

Perello M, Stuart RC \& Nillni EA 2006 The role of intracerebroventricular administration of leptin in the stimulation of prothyrotropin releasing hormone neurons in the hypothalamic paraventricular nucleus. Endocrinology 147 3296-3306. (doi:10.1210/en.2005-1533)

Perello M, Cakir I, Cyr NE, Romero A, Stuart RC, Chiappini F, Hollenberg AN \& Nillni EA 2010 Maintenance of the thyroid axis during diet-induced obesity in rodents is controlled at the central level. American Journal of Physiology. Endocrinology and Metabolism 299 E976-E989. (doi:10.1152/ ajpendo.00448.2010)

Pérez-Martínez L, Carreón-Rodríguez A, González-Alzati ME, Morales C, Charli JL \& Joseph-Bravo P 1998 Dexamethasone rapidly regulates TRH mRNA levels in hypothalamic cell cultures: interaction with the cAMP pathway. Neuroendocrinology 68 345-354. (doi:10.1159/000054383)

Pérez-Monter C, Martínez-Armenta M, Miquelajauregui A, Furlan-Magaril M, Varela-Echavarría A, Recillas-Targa F, May V, Charli JL \& Pérez-Martínez L 2011 The Krüppel-like factor 4 controls biosynthesis of thyrotropinreleasing hormone during hypothalamus development. Molecular and Cellular Endocrinology 333 127-133. (doi:10.1016/j.mce.2010.12.020)

Pervanidou P \& Chrousos GP 2012 Metabolic consequences of stress during childhood and adolescence. Metabolism 61 611-619. (doi:10.1016/ j.metabol.2011.10.005)

Ramadoss P, Abraham BJ, Tsai L, Zhou Y, Costa-e-Sousa RH, Ye F, Bilban M, Zhao K \& Hollenberg AN 2014 Novel mechanism of positive versus negative regulation by thyroid hormone receptor $\beta 1$ (TR $\beta 1$ ) identified by genome wide profiling of binding sites in mouse liver. Journal of Biological Chemistry 289 313-328. (doi:10.1074/jbc.M113.521450)

Randich A, Chandler PC, Mebane HC, Turnbach ME, Meller ST, Kelm GR \& Cox JE 2004 Jejunal administration of linoleic acid increases activity of neurons in the paraventricular nucleus of the hypothalamus. American Journal of Physiology. Regulatory, Integrative and Comparative Physiology 286 R166-R173. (doi:10.1152/ajpregu.00431.2003)

Raptis S, Fekete C, Sarkar S, Rand WM, Emerson CH, Nagy GM \& Lechan RM 2004 Cocaine- and amphetamineregulated transcript co-contained in thyrotropin-releasing hormone (TRH) neurons of the hypothalamic paraventricular nucleus modulates TRH-induced prolactin secretion. Endocrinology 145 1695-1699. (doi:10.1210/en.2003-1576)

Ratman D, Berghe WV, Dejager L, Libert C, Tavernier J, Beck IM \& De Bosscher K 2013 How glucocorticoid receptors modulate the activity of other transcription factors: a scope beyond tethering. Molecular and Cellular Endocrinology 380 41-54. (doi:10.1016/j.mce.2012.12.014)

Ren Y, Satoh T, Yamada M, Hashimoto K, Konaka S, Iwasaki T \& Mori M 1998 Stimulation of the preprothyrotropin-releasing hormone gene by epidermal growth factor. Endocrinology 139 195-203. (doi:10.1210/endo.139.1.5703)

Rodrigues AL, de Moura EG, Passos MC, Dutra SC \& Lisboa PC 2009 Postnatal early overnutrition changes the leptin signalling pathway in the hypothalamic-pituitary-thyroid axis of young and adult rats. Journal of Physiology 587 2647-2661. (doi:10.1113/jphysiol.2009.169045)

Rondeel JM, de Greef WJ, Hop WC, Rowland DL \& Visser TJ 1991 Effect of cold exposure on the hypothalamic release of thyrotropin-releasing hormone and catecholamines. Neuroendocrinology 54 477-481. (doi:10.1159/000125940)

Rondeel JM, Heide R, de Greef WJ, van Toor H, van Haasteren GA, Klootwijk W \& Visser TJ 1992 Effect of starvation and subsequent refeeding on thyroid function and release of hypothalamic thyrotropin-releasing hormone. Neuroendocrinology 56 348-353. (doi:10.1159/000126248)

Rorato R, Miyahara C, Antunes-Rodrigues J \& Elias LL 2013 Tolerance to hypophagia induced by prolonged treatment with a CB1 antagonist is related to the reversion of anorexigenic neuropeptide gene expression in the hypothalamus. Regulatory Peptides 182 12-18. (doi:10.1016/ j.regpep.2012.12.004)

Rose AJ \& Herzig S 2013 Metabolic control through glucocorticoid hormones: an update. Molecular and Cellular Endocrinology 380 65-78. (doi:10.1016/j.mce.2013.03.007)

Rosene ML, Wittmann G, Arrojo e Drigo R, Singru PS, Lechan RM \& Bianco AC 2010 Inhibition of the type 2 iodothyronine deiodinase underlies the elevated plasma TSH associated with amiodarone treatment. Endocrinology 151 5961-5970. (doi:10.1210/en.2010-0553)

Rothman SM, Griffioen KJ, Wan R \& Mattson MP 2012 Brain-derived neurotrophic factor as a regulator of systemic and brain energy metabolism and cardiovascular health. Annals of the New York Academy of Sciences 1264 49-63. (doi:10.1111/j.1749-6632.2012.06525.x)

RSPCA 2011 Rats: good practice for housing and care. Research Animals Department, RSPCA, 3rd Edition. http://science.rspca.org.uk/sciencegroup/researchanimals/ethicalreview/functionstasks/housingandcare

Sánchez E, Uribe RM, Corkidi G, Zoeller RT, Cisneros M, Zacarias M, Morales-Chapa C, Charli JL \& Joseph-Bravo P 2001 Differential responses of thyrotropin-releasing hormone (TRH) neurons to cold exposure or suckling indicate functional heterogeneity of the TRH system in the paraventricular nucleus of the rat hypothalamus. Neuroendocrinology 74 407-422. (doi:10.1159/000054707)

Sánchez E, Fekete C, Lechan RM \& Joseph-Bravo P 2007 Cocaine- and amphetamine-regulated transcript (CART) expression is differentially regulated in the hypothalamic paraventricular nucleus of lactating rats exposed to suckling or cold stimulation. Brain Research 1132 120-128. (doi:10.1016/j.brainres.2006.11.020)

Sánchez E, Singru PS, Acharya R, Bodria M, Fekete C, Zavacki AM, Bianco AC \& Lechan RM 2008 Differential effects of refeeding on melanocortinresponsive neurons in the hypothalamic paraventricular nucleus. Endocrinology 149 4329-4335. (doi:10.1210/en.2008-0411)

Sánchez E, Vargas MA, Singru PS, Pascual I, Romero F, Fekete C, Charli JL \& Lechan RM 2009 Tanycyte pyroglutamyl peptidase II contributes to regulation of the hypothalamic-pituitary-thyroid axis through glial-axonal associations in the median eminence. Endocrinology 150 2283-2291. (doi:10.1210/en.2008-1643)

Sarkar S, Légrádi G \& Lechan RM 2002 Intracerebroventricular administration of $\alpha$-melanocyte stimulating hormone increases phosphorylation of CREB in TRH- and CRH-producing neurons of the hypothalamic paraventricular nucleus. Brain Research 945 50-59. (doi:10.1016/S0006-8993(02)02619-7) 
Sárvári A, Farkas E, Kádár A, Zséli G, Füzesi T, Lechan RM \& Fekete C 2012 Thyrotropin-releasing hormone-containing axons innervate histaminergic neurons in the tuberomammillary nucleus. Brain Research $148872-80$. (doi:10.1016/j.brainres.2012.10.010)

Schneeberger M, Gomis R \& Claret M 2014 Hypothalamic and brainstem neuronal circuits controlling homeostatic energy balance. Journal of Endocrinology 220 T25-T46. (doi:10.1530/JOE-13-0398)

Schneider E, Neumann D \& Seifert R 2014 Modulation of behavior by the histaminergic system: lessons from HDC-, $\mathrm{H}_{3} \mathrm{R}$ - and $\mathrm{H}_{4} \mathrm{R}$-deficient mice. Neuroscience and Biobehavioral Reviews 47C 101-121. (doi:10.1016/ j.neubiorev.2014.07.020)

Segerson TP, Kauer J, Wolfe HC, Mobtaker H, Wu P, Jackson IM \& Lechan RM 1987 Thyroid hormone regulates TRH biosynthesis in the paraventricular nucleus of the rat hypothalamus. Science 238 78-80. (doi:10.1126/science.3116669)

Selye H 1976 Forty years of stress research: principal remaining problems and misconceptions. Canadian Medical Association Journal 115 53-56.

Servatius RJ, Natelson BH, Moldow R, Pogach L, Brennan FX \& Ottenweller JE 2000 Persistent neuroendocrine changes in multiple hormonal axes after a single or repeated stressor exposures. Stress 3 263-274. (doi:10.3109/10253890009001132)

Shi ZX, Levy A \& Lightman SL 1993 The effect of dietary protein on thyrotropin-releasing hormone and thyrotropin gene expression. Brain Research 606 1-4. (doi:10.1016/0006-8993(93)91561-6)

Shintani M, Tamura Y, Monden M \& Shiomi H 2005 Thyrotropin-releasing hormone induced thermogenesis in Syrian hamsters: site of action and receptor subtype. Brain Research 1039 22-29. (doi:10.1016/j.brainres. 2005.01.040)

Silva JE 2011 Physiological importance and control of non-shivering facultative thermogenesis. Frontiers in Bioscience 3 352-371. (doi:10.2741/s156)

Simmons DM \& Swanson LW 2009 Comparison of the spatial distribution of seven types of neuroendocrine neurons in the rat paraventricular nucleus: toward a global 3D model. Journal of Comparative Neurology 516 423-441. (doi:10.1002/cne.22126)

Sotelo-Rivera I, Cote-Vélez A, Pérez-Maldonado A, Charli J \& Joseph-Bravo P 2012 Corticosterone interferes with the stimulatory effect of cAMP on proTRH transcription by promoting a GR-PKAc interaction and not through chromatin remodelling 15th International \& 14th European Congress of Endocrinology, Florence, Italy. Endocrine Abstracts 29 P1115

Sotelo-Rivera I, Jaimes-Hoy L, Cote-Vélez A, Espinoza-Ayala C, Charli JL \& Joseph-Bravo P 2014 An acute injection of corticosterone increases thyrotrophin releasing hormone expression in the paraventricular nucleus of the hypothalamus but interferes with the rapid hypothalamus pituitary thyroid axis response to cold in male rats. Journal of Neuroendocrinology 26 861-869. (doi:10.1111/jne.12224)

Steinacker JM, Brkic M, Simsch C, Nething K, Kresz A, Prokopchuk O \& Liu Y 2005 Thyroid hormones, cytokines, physical training and metabolic control. Hormone and Metabolic Research 37 538-544. (doi:10.1055/ s-2005-870419)

Stranahan AM, Lee K \& Mattson MP 2008 Central mechanisms of HPA axis regulation by voluntary exercise. Neuromolecular Medicine 10 118-127. (doi:10.1007/s12017-008-8027-0)

Sugrue ML, Vella KR, Morales C, Lopez ME \& Hollenberg AN 2010 The thyrotropin-releasing hormone gene is regulated by thyroid hormone at the level of transcription in vivo. Endocrinology 151 793-801. (doi:10.1210/en.2009-0976)

Suzuki T, Kohno H, Sakurada T, Tadano T \& Kisara K 1982 Intracranial injection of thyrotropin releasing hormone (TRH) suppresses starvation-induced feeding and drinking in rats. Pharmacology, Biochemistry, and Behavior 17 249-253. (doi:10.1016/0091-3057(82)90078-8)

Taché Y, Yang H, Miampamba M, Martinez V \& Yuan PQ 2006 Role of brainstem TRH/TRH-R1 receptors in the vagal gastric cholinergic response to various stimuli including sham-feeding. Autonomic Neuroscience 125 42-52. (doi:10.1016/j.autneu.2006.01.014)
Ubieta R, Uribe RM, González JA, García-Vázquez A, Pérez-Monter C, PérezMartínez L, Joseph-Bravo P \& Charli JL 2007 BDNF up-regulates pre-pro-TRH mRNA expression in the fetal/neonatal paraventricular nucleus of the hypothalamus. Properties of the transduction pathway. Brain Research 1174 28-38. (doi:10.1016/j.brainres.2007.08.026)

Umezawa R, Yamada M, Horiguchi K, Ishii S, Hashimoto K, Okada S, Satoh T \& Mori M 2009 Aberrant histone modifications at the thyrotropinreleasing hormone gene in resistance to thyroid hormone: analysis of F455S mutant thyroid hormone receptor. Endocrinology 150 3425-3432. (doi:10.1210/en.2008-1738)

Uribe RM, Joseph-Bravo P, Pasten J, Ponce G, Méndez M, Covarrubias L \& Charli JL 1991 Some events of thyrotropin-releasing hormone metabolism are regulated in lactating and cycling rats. Neuroendocrinology 54 493-498. (doi:10.1159/000125943)

Uribe RM, Redondo JL, Charli JL \& Joseph-Bravo P 1993 Suckling and cold stress rapidly and transiently increase TRH mRNA in the paraventricular nucleus. Neuroendocrinology 58 140-145. (doi:10.1159/000126523)

Uribe RM, Pérez-Martínez L, de Lourdes Covarrubias M, Gómez O, Covarrubias L, Charli JL \& Joseph-Bravo P 1995a Phorbol ester or cAMP enhance thyrotropin-releasing hormone mRNA in primary cultures of hypothalamic cells. Neuroscience Letters 201 41-44. (doi:10.1016/03043940(95)12125-N)

Uribe RM, Joseph-Bravo P \& Charli JL 1995b Pups removal enhances thyrotropin-releasing hormone mRNA in the hypothalamic paraventricular nucleus. European Journal of Endocrinology 133 354-360. (doi:10.1530/eje.0.1330354)

Uribe RM, Zacarias M, Corkidi G, Cisneros M, Charli JL \& Joseph-Bravo P 2009 $17 \beta$-Oestradiol indirectly inhibits thyrotrophin-releasing hormone expression in the hypothalamic paraventricular nucleus of female rats and blunts thyroid axis response to cold exposure. Journal of Neuroendocrinology 21 439-448. (doi:10.1111/j.1365-2826.2009.01861.x)

Uribe RM, Cisneros M, Vargas MA, Lezama L, Cote-Vélez A, Joseph-Bravo P \& Charli JL 2011 The systemic inhibition of nitric oxide production rapidly regulates TRH mRNA concentration in the paraventricular nucleus of the hypothalamus and serum TSH concentration. Studies in control and cold-stressed rats. Brain Research 1367 188-197. (doi:10.1016/j.brainres.2010.10.011)

Uribe RM, Jaimes-Hoy L, Ramírez-Martínez C, García-Vázquez A, Romero F, Cisneros M, Cote-Vélez A, Charli JL \& Joseph-Bravo P 2014 Voluntary exercise adapts the hypothalamus-pituitary-thyroid axis in male rats. Endocrinology 155 2020-2030. (doi:10.1210/en.2013-1724)

Valle A, Català-Niell A, Colom B, García-Palmer FJ, Oliver J \& Roca P 2005 Sex-related differences in energy balance in response to caloric restriction. American Journal of Physiology. Endocrinology and Metabolism 289 E15-E22. (doi:10.1152/ajpendo.00553.2004)

Vargas M, Mendez M, Cisneros M, Joseph-Bravo P \& Charli JL 1987 Regional distribution of the membrane-bound pyroglutamate amino peptidase-degrading thyrotropin-releasing hormone in rat brain. Neuroscience Letters 79 311-314. (doi:10.1016/0304-3940(87)90450-2)

Vella KR, Ramadoss P, Costa-E-Sousa RH, Astapova I, Ye FD, Holtz KA, Harris JC \& Hollenberg AN 2014 Thyroid hormone signaling in vivo requires a balance between coactivators and corepressors. Molecular and Cellular Biology 34 1564-1575. (doi:10.1128/MCB.00129-14)

Veyrat-Durebex C, Poher AL, Caillon A, Somm E, Vallet P, Charnay Y \& Rohner-Jeanrenaud F 2013 Improved leptin sensitivity as a potential candidate responsible for the spontaneous food restriction of the Lou/C rat. PLOS ONE 8 e73452. (doi:10.1371/journal.pone.0073452)

Wallis M 2010 Molecular evolution of the thyrotrophin-releasing hormone precursor in vertebrates: insights from comparative genomics. Journal of Neuroendocrinology 22 608-619. (doi:10.1111/j.1365-2826.2010.01996.x)

Watts AG, Sanchez-Watts G \& Kelly AB 1999 Distinct patterns of neuropeptide gene expression in the lateral hypothalamic area and arcuate nucleus are associated with dehydration-induced anorexia. Journal of Neuroscience 19 6111-6121.

Weber JM 2011 Metabolic fuels: regulating fluxes to select mix. Journal of Experimental Biology 214 286-294. (doi:10.1242/jeb.047050)

Published by Bioscientifica Ltd 
Wittmann G, Füzesi T, Singru PS, Liposits Z, Lechan RM \& Fekete C 2009a Efferent projections of thyrotropin-releasing hormone-synthesizing neurons residing in the anterior parvocellular subdivision of the hypothalamic paraventricular nucleus. Journal of Comparative Neurology 515 313-330. (doi:10.1002/cne.22017)

Wittmann G, Füzesi T, Liposits Z, Lechan RM \& Fekete C $2009 b$ Distribution and axonal projections of neurons coexpressing thyrotropin-releasing hormone and urocortin 3 in the rat brain. Journal of Comparative Neurology 517 825-840. (doi:10.1002/cne.22180)

Xia T, Zhang Q, Xiao Y, Wang C, Yu J, Liu H, Liu B, Zhang Y, Chen S, Liu Y et al. 2015 CREB/TRH pathway in the central nervous system regulates energy expenditure in response to deprivation of an essential amino acid. International Journal of Obesity 39 105-113. (doi:10.1038/ ijo.2014.65)

Yoo HS, Qiao L, Bosco C, Leong LH, Lytle N, Feng GS, Chi NW \& Shao J 2014 Intermittent cold exposure enhances fat accumulation in mice. PLOS ONE 9 e96432. (doi:10.1371/journal.pone.0096432)
Yuan PQ \& Yang H 1999 Hyperthyroidism decreases thyrotropin-releasing hormone gene expression in the caudal raphe nuclei and the parapyramidal regions in rats. Neuroscience Letters 276 189-192. (doi:10.1016/S0304-3940(99)00830-7)

Zhang X \& van den Pol AN 2012 Thyrotropin-releasing hormone (TRH) inhibits melanin-concentrating hormone neurons: implications for TRH-mediated anorexic and arousal actions. Journal of Neuroscience 32 3032-3043. (doi:10.1523/JNEUROSCI.5966-11.2012)

Zoeller TR 2010 Environmental chemicals targeting thyroid. Hormones 9 28-40. (doi:10.14310/horm.2002.1250)

Zoeller RT, Kabeer N \& Albers HE 1990 Cold exposure elevates cellular levels of messenger ribonucleic acid encoding thyrotropin-releasing hormone in paraventricular nucleus despite elevated levels of thyroid hormones. Endocrinology 127 2955-2962. (doi:10.1210/endo-127-6-2955)

Zoeller RT, Simonyi A, Butnariu O, Fletcher DL, Rudeen PK, McCrone S \& Petersen SL 1995 Effects of acute ethanol administration and cold exposure on the hypothalamic-pituitary-thyroid axis. Endocrine 3 39-47. (doi:10.1007/BF02917447)

Received in final form 4 December 2014

Accepted 6 January 2015

Accepted Preprint published online 6 January 2015
(C) 2015 Society for Endocrinology Printed in Great Britain
Published by Bioscientifica Ltd. 